
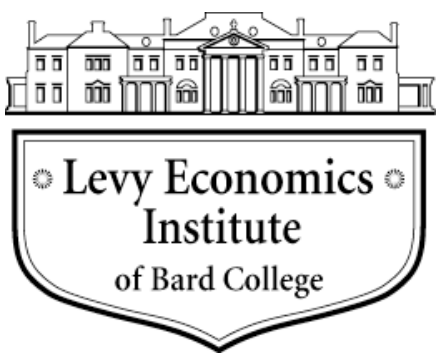

Working Paper No. 746

\title{
Finance-dominated Capitalism and Redistribution of Income: A Kaleckian Perspective
}

\author{
by \\ Eckhard Hein* \\ Berlin School of Economics and Law \\ and Institute for International Political Economy, Berlin
}

January 2013

* This paper is based on chapter 2 of my book The Macroeconomics of Finance-dominated Capitalism - and Its Crisis (2012), and it updates and extends the analysis provided there. Correspondence: eckhard.hein@hwrberlin.de.

The Levy Economics Institute Working Paper Collection presents research in progress by Levy Institute scholars and conference participants. The purpose of the series is to disseminate ideas to and elicit comments from academics and professionals.

Levy Economics Institute of Bard College, founded in 1986, is a nonprofit, nonpartisan, independently funded research organization devoted to public service. Through scholarship and economic research it generates viable, effective public policy responses to important economic problems that profoundly affect the quality of life in the United States and abroad.

\footnotetext{
Levy Economics Institute

P.O. Box 5000

Annandale-on-Hudson, NY 12504-5000

http://www.levyinstitute.org
}

Copyright (C) Levy Economics Institute 2013 All rights reserved

ISSN 1547-366X 


\begin{abstract}
This paper examines a major channel through which financialization or finance-dominated capitalism affects macroeconomic performance: the distribution channel. Empirical data for the following dimensions of redistribution in the period of finance-dominated capitalism since the early 1980s is provided for 15 advanced capitalist economies: functional distribution, personal/household distribution, and the share and composition of top incomes. Based on the Kaleckian approach to the determination of income shares, the effects of financialization on functional income distribution are studied in more detail. Some stylized facts of financialization are integrated into the Kaleckian approach, and by means of reviewing empirical and econometric literature it is found that financialization and neoliberalism have contributed to the falling labor income share since the early 1980s through three main Kaleckian channels: (1) a shift in the sectoral composition of the economy; (2) an increase in management salaries and rising profit claims of the rentiers, and thus in overheads; and (3) weakened trade union bargaining power.
\end{abstract}

Keywords: Finance-dominated Capitalism; Distribution of Income; Kaleckian Price and Distribution Theory

JEL Classifications: D31, D33, D43 


\section{INTRODUCTION}

It is by now widely agreed upon among non-orthodox authors that the severity of the financial and economic crises in the period 2007-12 has been caused by changes in income distribution over the last decades and the emerging current account imbalances at the global and at regional (euro area) levels, apart from malfunctioning deregulated financial markets. ${ }^{1}$ These developments have been determined by the policies aimed at deregulation of labor markets, reduction of government intervention into the market economy and of government demand management, redistribution of income from (lower) wages to profits and top management salaries, and deregulation and liberalization of national and international financial markets. This broad policy stance may be called "neo-liberalism," describing the policies implemented-to different degrees in different capitalist economies — since the early 1980s or later.

"Financialization," or "finance-dominated capitalism" (we use these terms interchangeably), is interrelated and overlaps with neo-liberalism. ${ }^{2}$ Epstein $(2005$, p. 3) has presented a widely accepted definition, arguing that "[...] financialization means the increasing role of financial motives, financial markets, financial actors and financial institutions in the operation of the domestic and international economies."

The instabilities and crises the world economy has been facing for the last couple of years can therefore be understood as crises of neo-liberalism and finance-dominated capitalism. The detailed features of financialization or finance-dominated capitalism have been described and analyzed extensively and in detail by many authors. ${ }^{3}$ From a macroeconomic perspective, we have claimed that finance-dominated capitalism has affected long-run economic developments through the following three main channels (Hein 2012):

1. With regard to distribution, financialization has been conducive to a rising gross profit share (including retained profits, dividends, and interest payments), and thus a falling

\footnotetext{
${ }^{1}$ On global imbalances and unequal distribution as causes for the present crisis, on top of widely accepted inefficient regulation of the financial sector, see for example, with different emphasis, also Bibow (2008), Fitoussi and Stiglitz (2009), Horn et al. (2009), Sapir (2009), Stockhammer (2010a, 2010b), UNCTAD (2009), van Treeck and Sturn (2012), and Wade (2009). For a review of the changes in worldwide financial markets and related imbalances that fed the financial crisis see, for example, Guttmann (2009).

${ }^{2}$ See Stockhammer (2010a, 2010b) for a similar distinction and Palma (2009) for a more extensive discussion of the relationship between neo-liberalism and the present crisis.

${ }^{3}$ See, for example, Krippner (2005), Palley (2008), and the contributions in Epstein (2005) for a detailed treatment of the development of financialization in the US, van Treeck (2009) and van Treeck, Hein, and Dünhaupt (2007) for a more detailed comparison of the macroeconomics of financialization in the US and Germany, and Stockhammer (2008) for the development in Europe.
} 
labor income share on the one hand; and to increasing inequality of wages and top management salaries, and thus of personal or household incomes on the other hand.

2. Regarding investment in capital stock, financialization has caused increasing shareholder power vis-à-vis firms and workers, an increasing rate of return on equity and bonds held by rentiers, and an alignment of management with shareholder interests through shortrun performance-related pay schemes, bonuses, stock option programs, etc. On the one hand, this has imposed short-termism on management. This meant a decrease in management's "animal spirits" with respect to real investment in capital stock and longrun growth of the firm, and an increase in the preference for financial investment, generating high profits in the short run. On the other hand, it has drained internal means of finance available for real investment purposes from the corporations, through increasing dividend payments and share buybacks in order to boost stock prices and thus shareholder value. These "preference" and "internal means of finance" channels have each had partially negative effects on firms' real investment in capital stock, and hence on long-run growth of the economy to the extent that productivity growth is capital embodied.

3. Regarding consumption, financialization has generated an increasing potential for wealth-based and debt-financed consumption, thus creating the potential to compensate for the depressive demand effects of financialization, which were imposed on the economy via redistribution and the impact on real investment. Stock market and housing price booms have each increased notional wealth against which households were willing to borrow. Changing financial norms, new financial instruments (e.g., credit card debt and home equity lending), and deterioration of creditworthiness standards, triggered by securitization of mortgage debt and "originate and distribute" strategies of commercial banks, made increasing credit available to low-income, low-wealth households, in particular. This allowed consumption to rise faster than median income, thus stabilizing aggregate demand. But it also generated increasing debt-income ratios of private households and thus increasing financial fragility for the economy as a whole. Against the background of these basic macroeconomic tendencies of finance-dominated capitalism, rising current account imbalances at the global, but also at the European level, have developed and contributed to the severity of the Great Recession of 2008-09. Some countries relied on debt-led soaring private consumption demand as the main driver of aggregate demand 
and GDP growth, generating and accepting concomitant rising deficits in their trade and current account balances. Other countries focused on mercantilist export-led strategies as an alternative to generating demand in the face of redistribution at the expense of (low) labor incomes, stagnating consumption demand, and weak real investment - and have hence accumulated increasing surpluses in their trade and current account balances.

In this paper, we will focus on the first and maybe most basic channel for the macroeconomic effects of financialization mentioned above and will provide a deeper investigation into the relationship between financialization and income distribution. In Section 2, we will start with an empirical overview of different dimensions of (re-)distribution in the period of finance-dominated capitalism since the early 1980s: functional distribution; personal/household distribution; and finally, the share and composition of top incomes. Then, in Section 3, we will focus on functional distribution and will provide a Kaleckian analysis of the main channels through which neo-liberalism and finance-dominated capitalism have influenced the tendency of the labor income share to fall as observed in this period. In Section 4, some empirical evidence for these channels of influence will be reviewed. Section 5 will summarize and conclude.

\section{TRENDS OF REDISTRIBUTION SINCE THE EARLY 1980s}

The trend toward redistribution under the conditions of finance-dominated capitalism has several empirical dimensions which will be examined here for the major founding Euro area countries, Austria, Belgium, Finland, France, Germany, Greece, Ireland, Italy, the Netherlands, Portugal, and Spain; Sweden and the UK as EU countries outside the euro area; and the US and Japan.

First, we observe that functional income distribution has changed at the expense of labor and in favor of broad capital income in the period of neo-liberalism and finance-dominated capitalism. The labor income share, as a measure taken from the national accounts and corrected for the changes in the composition of employment regarding employees and self-employed, ${ }^{4}$ has shown a falling trend in the developed capitalist economies considered here from the early 1980s, at the latest, until the Great Recession, with cyclical fluctuations due to the well known counter-cyclical properties of the labor income share (Figures 1a-1d). This trend is most

\footnotetext{
${ }^{4}$ The labor income share is given by the compensation per employee divided by GDP at factor costs per person employed. European Commission (2012), from which our data is taken, calls this the "adjusted wage share."
} 
pronounced in those euro area countries which we have classified elsewhere as "debt-led consumption boom" countries before the crisis, Greece, Ireland, and Spain (Figure 1a). ${ }^{5}$ However, it is also clearly visible in those euro area countries that can be classified as "exportled mercantilist" economies, Austria, Belgium, Finland, Germany, and the Netherlands (Figure 1b). In the "domestic demand-led" economies it is less clearly visible: France and Italy have seen a fall in the labor income share mainly from the early 1980s until the early/mid-1990s and a roughly constant share since then. In Portugal there was a massive decline (after a steep rise) from the mid-1970s until the mid-1980s and the labor income share has remained almost constant since then. The four non-euro area countries in our dataset have all seen a tendency of a falling labor income share since the early 1980s. This is true for the "export-led mercantilist" countries in this group, Sweden and Japan, as well as for the "debt-led consumption boom" economies, the UK and the US, albeit to a different degree. The reasons for these long-run developments and their relationships with neo-liberalism and finance-dominated capitalism will be examined more closely in Section 3 of this paper. Before, we will take a look at two further dimensions of redistribution.

Figure 1a Labor income share as percentage of GDP at current factor costs in Greece, Ireland, and Spain, 19602012

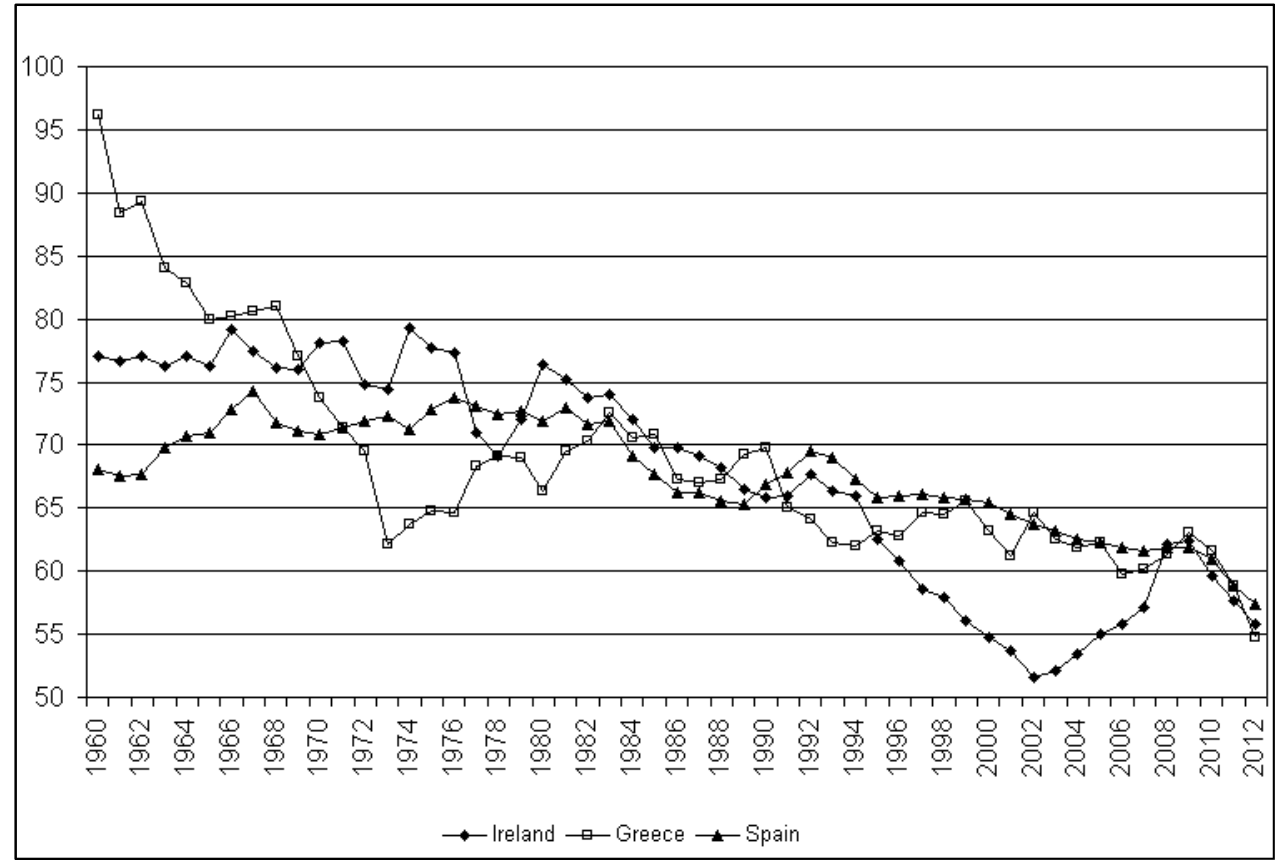

Source: European Commission (2012)

${ }^{5}$ See Hein (2012, Chapters 6 and 8) for a typology of the pre-crisis development that distinguishes "debt-led consumption boom" economies from "export-led mercantilist" and "domestic demand-led" economies. See Hein and Mundt (2012) for an application of this typology to the G20 economies. 
Figure $1 b$ Labor income share as percentage of GDP at current factor costs in Austria, Belgium, Finland, Germany, and the Netherlands, 1960-2012

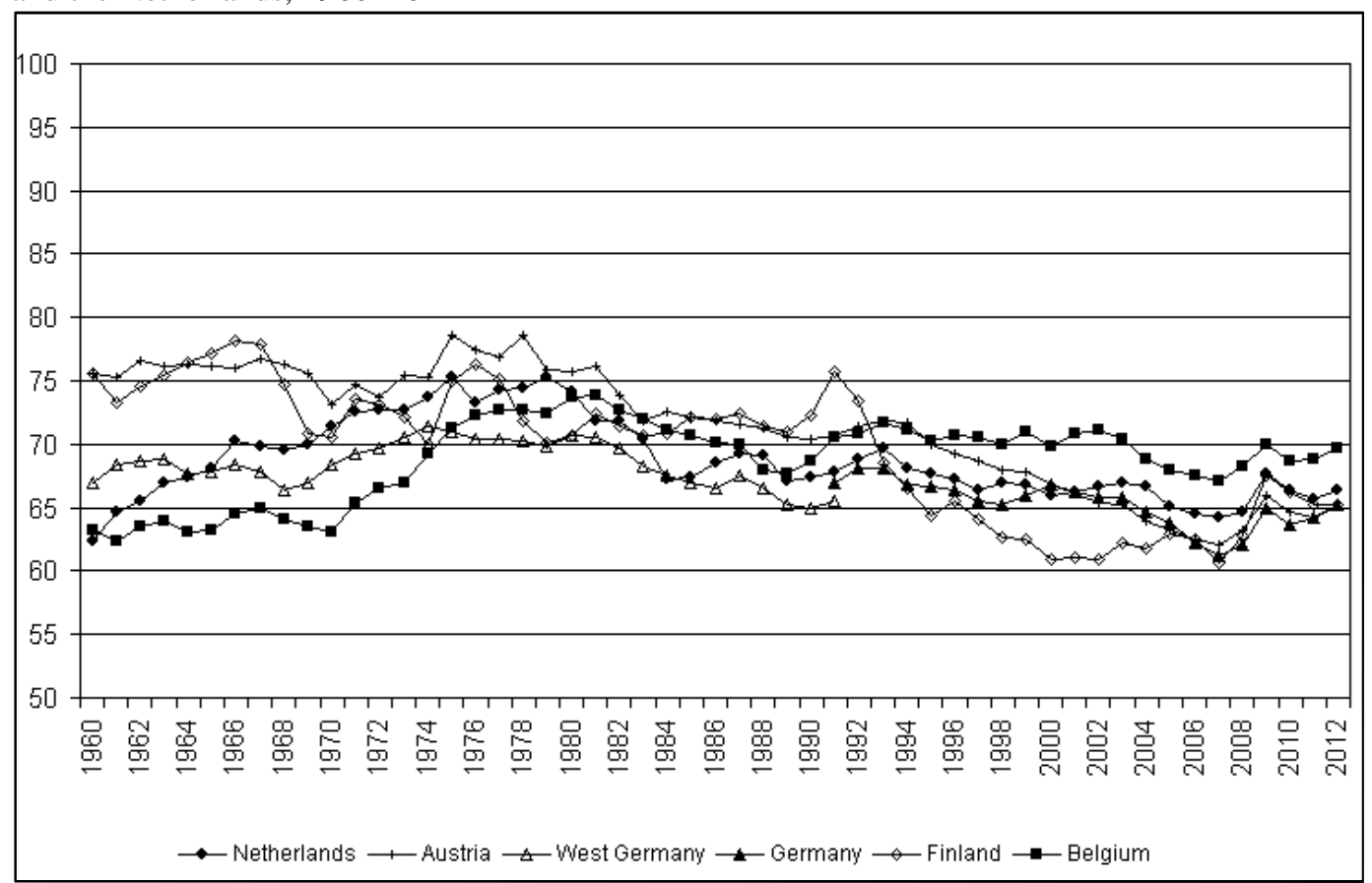

Source: European Commission (2012)

Notes: 1960-1991: West Germany; 1991-2012: Germany

Figure 1c Labor income share as percentage of GDP at current factor costs in France, Italy, and Portugal, 19602012

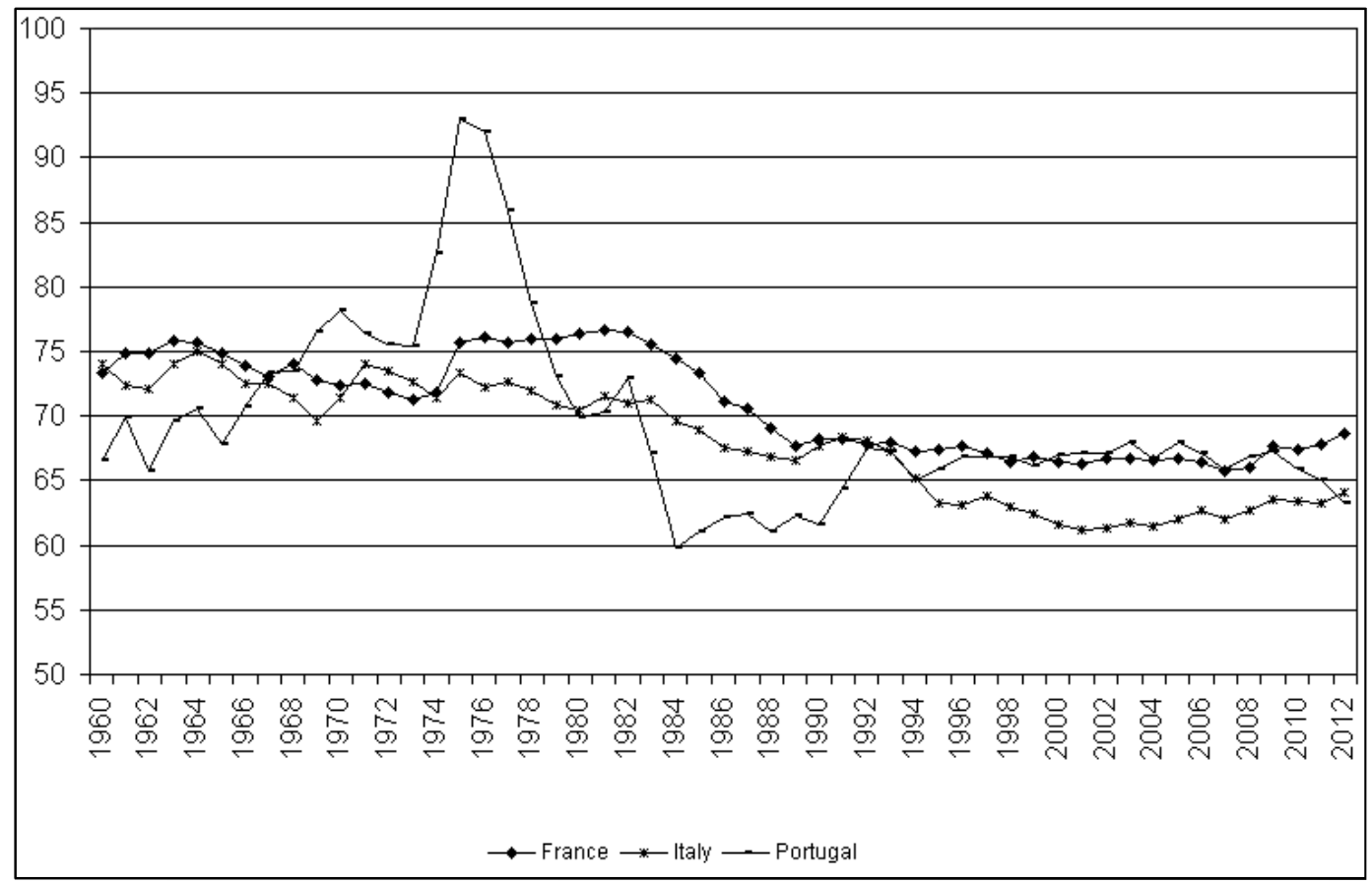

Source: European Commission (2012) 
Figure $1 d$ Labor income share as percentage of GDP at current factor costs in Sweden, the UK, the US, and Japan, 1960-2012

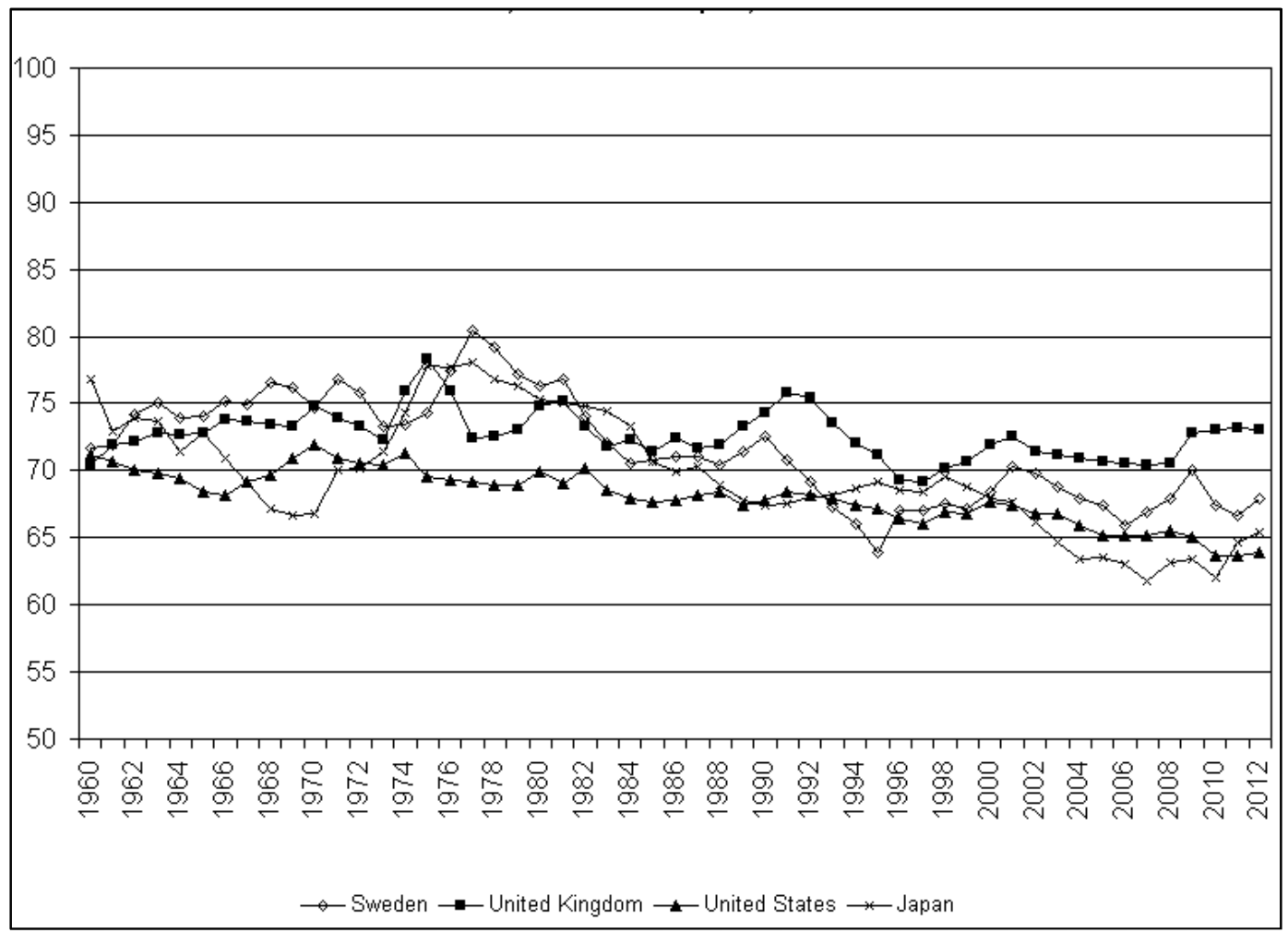

Source: European Commission (2012)

Second, personal income distribution has become more unequal in most of the countries from the mid-1980s until the late 2000s. Taking the Gini coefficient as an indicator, this is true for the distribution of market income, with the Netherlands being the only exception in our dataset (Table 1). In some countries the rise in inequality has been considerable, in particular in Finland, Germany, Italy, Portugal, the UK, and the US. If we include redistribution via taxes and social policies by the state and take a look at the distribution of disposable income, we find that Belgium, France, Greece, Ireland, and Spain have not seen an increase in their Gini coefficients. On the contrary, the Gini coefficient has declined and disposable income distribution has become less unequal. The other countries, however, have also experienced increasing inequality in distribution of disposable income in the period of neo-liberalism and finance-dominated capitalism. This increase was particularly pronounced in Finland, Germany, Sweden, the UK, and the US. Although tax and social policies have reduced income inequality in all of the countries under investigation, in most countries this has not prevented an increase in inequality over time. This is also the conclusion that the Organisation for Economic Co- 
operation and Development has drawn for a broader set of countries and from the application of further measures of income inequality (OECD 2008, 2011).

Table 1

\begin{tabular}{|c|c|c|c|c|c|c|c|}
\hline \multicolumn{8}{|c|}{ Gini coefficient before taxes for households' market income } \\
\hline Country & mid-80s & $\begin{array}{c}\text { around } \\
1990\end{array}$ & mid-90s & $\begin{array}{c}\text { around } \\
2000\end{array}$ & mid-2000s & late $2000 \mathrm{~s}$ & $\begin{array}{c}\text { Change from } \\
\text { mid-80s/around } \\
\text { 1990/mid 90s } \\
\text { until late 2000s }\end{array}$ \\
\hline Austria & .. & .. & .. & .. & 0.433 & 0.472 & .. \\
\hline Belgium & 0.449 & .. & 0.472 & 0.464 & 0.494 & 0.469 & 0.020 \\
\hline Finland & 0.387 & .. & 0.479 & 0.478 & 0.483 & 0.465 & 0.078 \\
\hline France & .. & .. & 0.473 & 0.490 & 0.485 & 0.483 & 0.010 \\
\hline Germany & 0.439 & 0.429 & 0.459 & 0.471 & 0.499 & 0.504 & 0.065 \\
\hline Greece & 0.426 & .. & 0.446 & 0.466 & 0.454 & 0.436 & 0.010 \\
\hline Ireland & .. & .. & .. & .. &.. & .. & .. \\
\hline Italy & 0.420 & 0.437 & 0.508 & 0.516 & 0.557 & 0.534 & 0.114 \\
\hline Netherlands & 0.473 & 0.474 & 0.484 & 0.424 & 0.426 & 0.426 & -0.047 \\
\hline Portugal &.. & 0.436 & 0.490 & 0.479 & 0.542 & 0.521 & 0.085 \\
\hline Spain &.. & .. &.. &.. &.. & 0.461 &.. \\
\hline Sweden & 0.404 & 0.408 & 0.438 & 0.446 & 0.432 & 0.426 & 0.022 \\
\hline UK & 0.419 & 0.439 & 0.453 & 0.512 & 0.500 & 0.506 & 0.087 \\
\hline US & 0.436 & 0.450 & 0.477 & 0.476 & 0.486 & 0.486 & 0.050 \\
\hline Japan & 0.345 & .. & 0.403 & 0.432 & 0.443 & 0.462 & 0.117 \\
\hline \multicolumn{8}{|c|}{ Gini coefficient after taxes for households' disposable income } \\
\hline Country & mid-80s & $\begin{array}{c}\text { around } \\
1990\end{array}$ & mid-90s & $\begin{array}{c}\text { around } \\
2000\end{array}$ & mid-2000s & late $2000 \mathrm{~s}$ & $\begin{array}{c}\text { Change mid- } \\
\text { 80s/around 1990 } \\
\text { until late 2000s }\end{array}$ \\
\hline Austria & 0.236 & .. & 0.238 & 0.252 & 0.265 & 0.261 & 0.025 \\
\hline Belgium & 0.274 & .. & 0.287 & 0.289 & 0.271 & 0.259 & -0.015 \\
\hline Finland & 0.209 & .. & 0.218 & 0.247 & 0.254 & 0.259 & 0.050 \\
\hline France & 0.300 & 0.290 & 0.277 & 0.287 & 0.288 & 0.293 & -0.007 \\
\hline Germany & 0.251 & 0.256 & 0.266 & 0.264 & 0.285 & 0.295 & 0.044 \\
\hline Greece & 0.336 & .. & 0.336 & 0.345 & 0.321 & 0.307 & -0.029 \\
\hline Ireland & 0.331 &.. & 0.324 & 0.304 & 0.314 & 0.293 & -0.038 \\
\hline Italy & 0.309 & 0.297 & 0.348 & 0.343 & 0.352 & 0.337 & 0.028 \\
\hline Netherlands & 0.272 & 0.292 & 0.297 & 0.292 & 0.284 & 0.294 & 0.022 \\
\hline Portugal & .. & 0.329 & 0.359 & 0.356 & 0.385 & 0.353 & 0.024 \\
\hline Spain & 0.371 & 0.337 & 0.343 & 0.342 & 0.319 & 0.317 & -0.054 \\
\hline Sweden & 0.198 & 0.209 & 0.211 & 0.243 & 0.234 & 0.259 & 0.061 \\
\hline UK & 0.309 & 0.354 & 0.336 & 0.352 & 0.331 & 0.342 & 0.033 \\
\hline US & 0.337 & 0.348 & 0.361 & 0.357 & 0.38 & 0.378 & 0.041 \\
\hline Japan & 0.304 &.. & 0.323 & 0.337 & 0.321 & 0.329 & 0.025 \\
\hline
\end{tabular}

Note: Gini coefficient is based on equivalized household income

Source: OECD (2012), author's calculations 
Third, the path-breaking research by Piketty and Saez $(2003,2006)$ based on tax data for the US has shown that, with regard to changes in personal income distribution, the share of top incomes in national income has increased significantly since the early 1980s in the US. ${ }^{6}$ Studies based on tax data, which have by now been extended to several other countries and have been reviewed in Atkinson, Piketty, and Saez (2011), focus on the distribution of market income prior to taxation and government redistribution. Making use of the data from the World Top Incomes Database provided by Alvaredo et al. (2012), we take a look at the developments of the income shares of the top 0.1 percent, excluding realized net capital gains because of their wide procyclical fluctuations, in 11 countries in Figures $2 \mathrm{a}-2 \mathrm{e} .^{7}$ The US and the UK have seen an explosion of the shares of the very top incomes since the early 1980s, which prior to the present crisis have again reached levels of the mid-1920s in the US and the mid-1930s in the UK. In France, Germany, the Netherlands, Spain, Portugal, Italy, Ireland, Japan, and Sweden, however, the shares of the top 0.1 percent have not returned to the high levels seen prior to World War II. However, with the exception of Germany, Ireland, and the Netherlands, also in these countries a slightly upward trend can be observed since the early 1980s. For Ireland, Atkinson, Piketty, and Saez (2011) and the data provided by Alvaredo et al. (2012), however, show a clearly rising trend for the top 1 percent share in national income since the mid-1980s. And for Germany, it should be noted that the share of the top 0.1 percent (Figure $2 b$ ) is substantially higher than in the other countries and has only been surpassed by the US and the UK since the mid-1980s and the mid-1990s, respectively. Furthermore, if we use the updated series provided by Alvaredo et al. (2012) including realized net capital gains, there might have been a slightly upward tendency from the early 1980s until the Great Recession (Figure 2b). In the dataset by Alvaredo et al. (2012) this is even more visible for the top 5 and the top 10 percent including net capital gains. Furthermore, Bach, Corneo, and Steiner (2009), in a study on income distribution in Germany from 1992-2003 merging household and consumer survey data from the German Socio Economic Panel with data from official income tax statistics, thus creating a database for the entire income distribution, confirm no rising tendency of top 0.1 income shares excluding capital gains until 2003. But they find remarkable growth of the income share accruing to the richest 0.001 percent of the population (about 650 persons), which managed to increase its share

\footnotetext{
${ }^{6}$ For studies on the US, see, also, Dew-Becker and Gordon (2005), Gordon and Dew-Becker (2007), Mohun (2006) and Dumenila and Levy (2004b). The latter provide a more extended interpretation of the results by Piketty and Saez (2003) for the US against the background of financialization.

${ }^{7}$ Austria, Belgium, Finland, and Greece are not in the dataset supplied by Alvaredo et al. (2012).
} 
of gross market income-excluding capital gains-from 0.55 percent in 1992 to 0.82 percent in $2003 .^{8}$

Figure $2 a$ Top 0.1 percent share in national income in the UK and the US, in percent

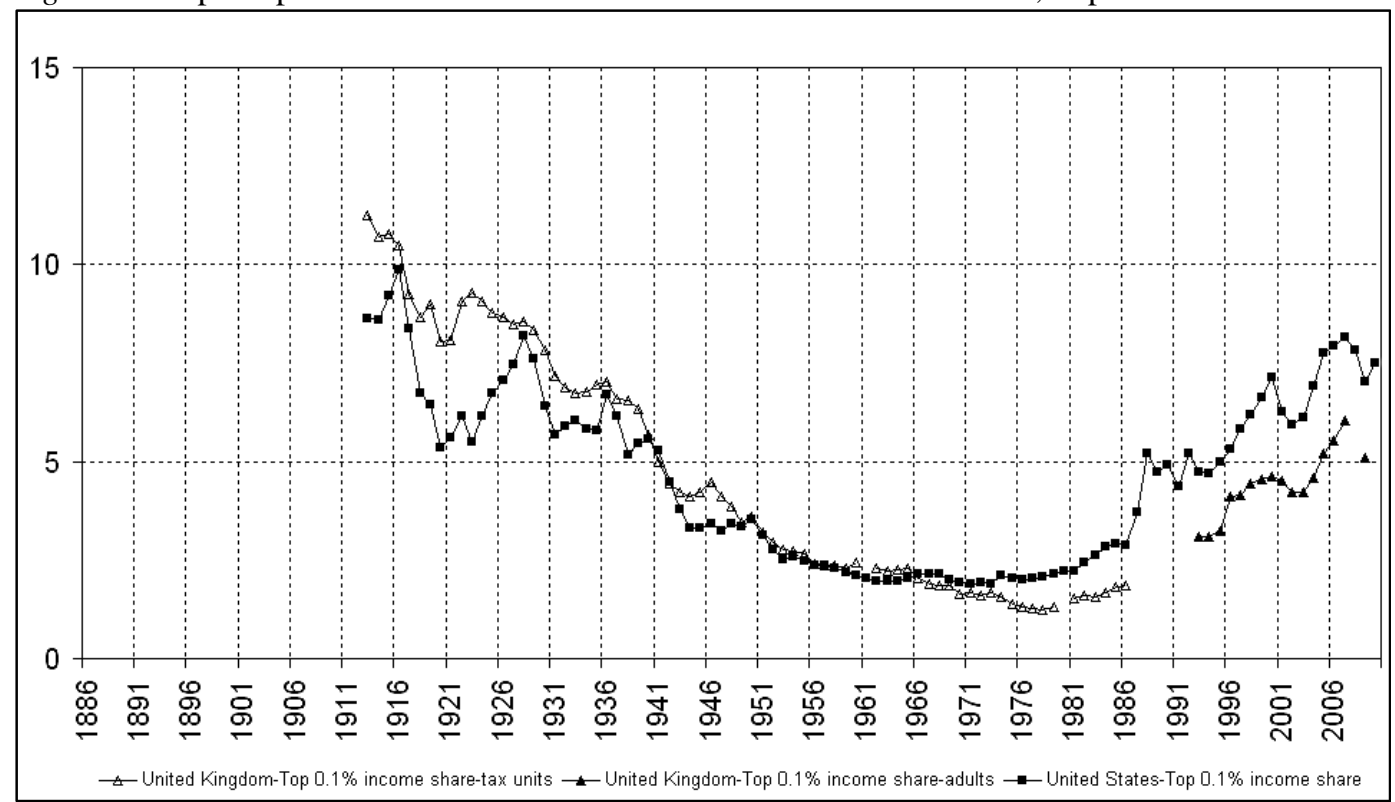

Source: Alvaredo et al. (2012)

Figure $2 b$ Top 0.1 percent share in national income in Germany and the Netherlands, in percent

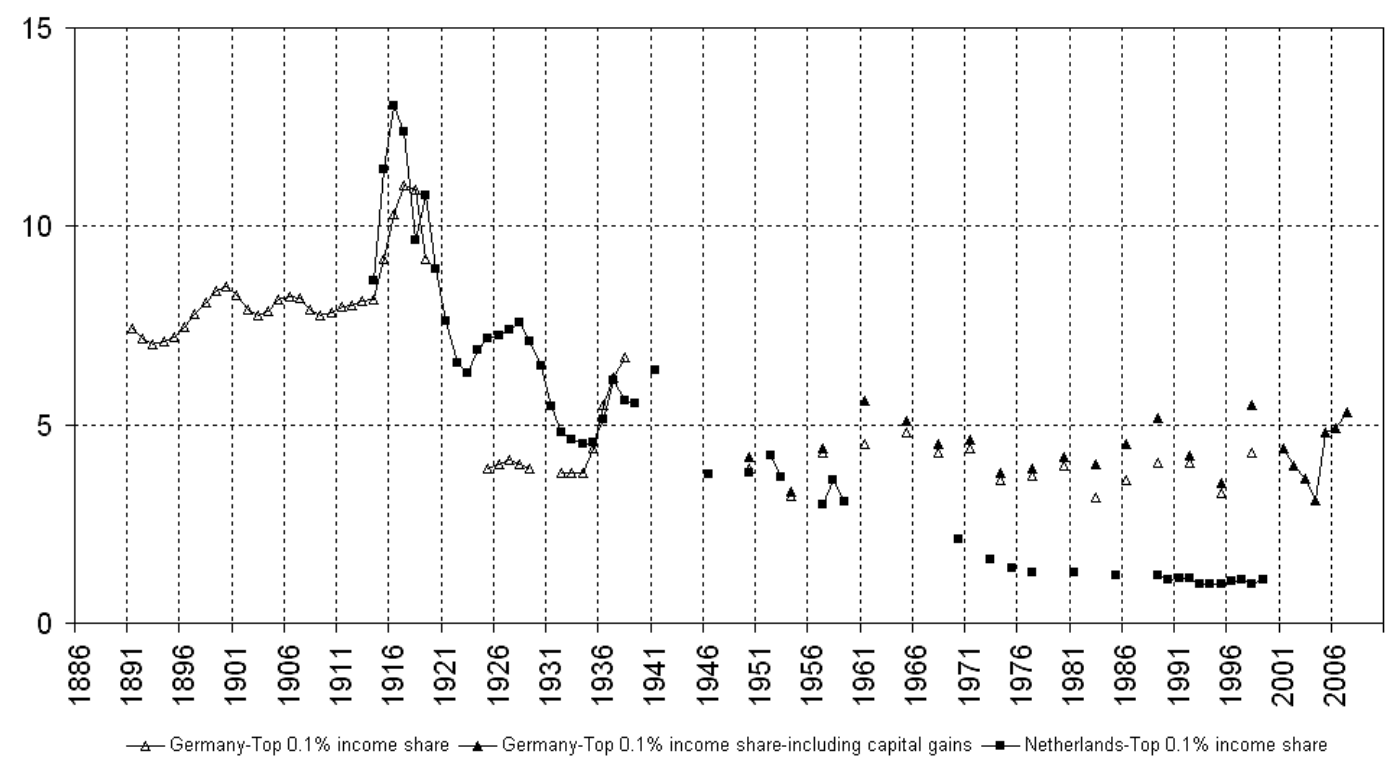

Source: Alvaredo et al. (2012)

\footnotetext{
${ }^{8}$ See Anselmann and Krämer (2012) for a more detailed analysis of German top incomes based on data sources provided by Alvaredo et al. (2012) and Bach, Corneo, and Steiner (2009).
} 
Figure $2 c$ Top 0.1 percent share in national income in France, Italy, and Portugal, in percent

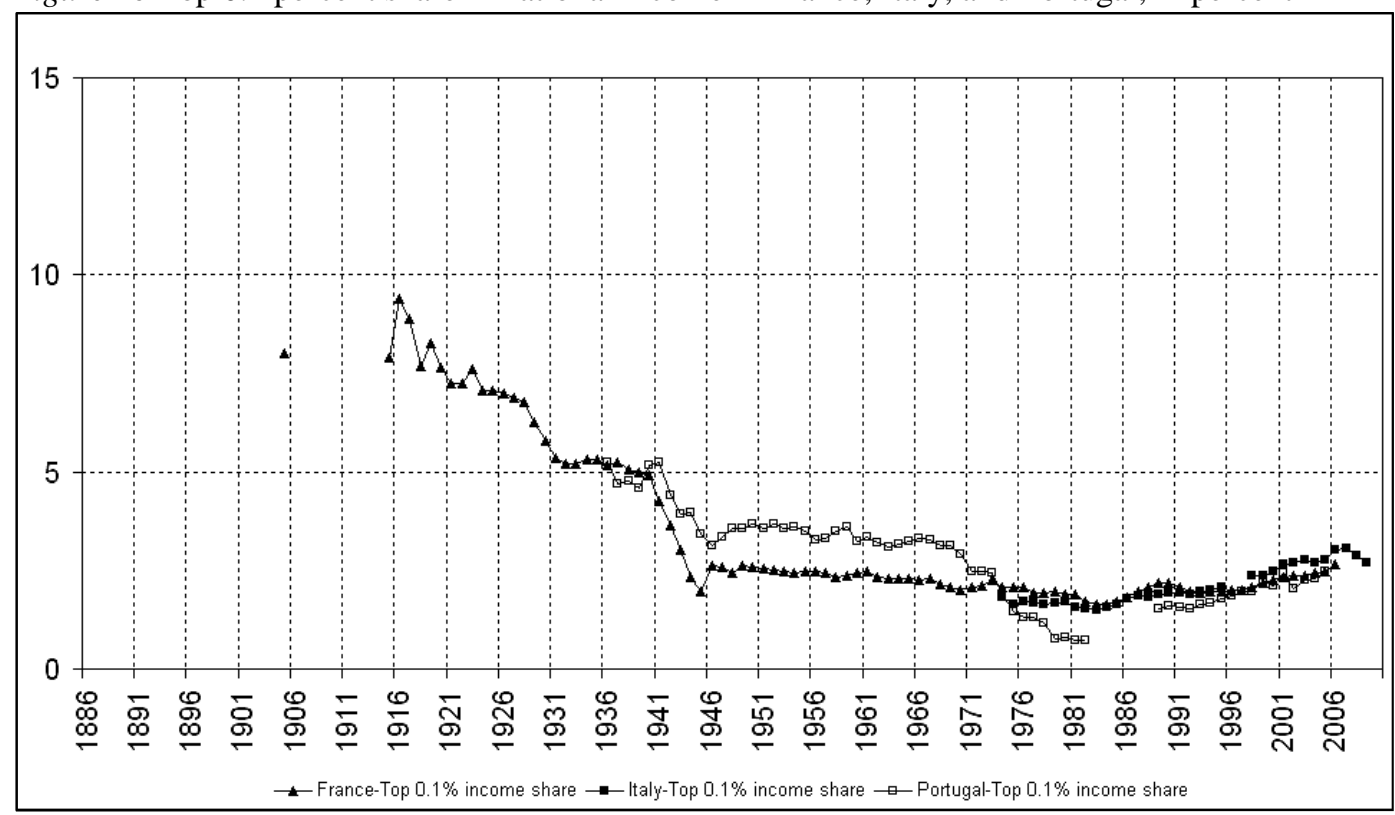

Source: Alvaredo et al. (2012)

Figure $2 d$ Top 0.1 percent share in national income in Ireland and Spain, in percent

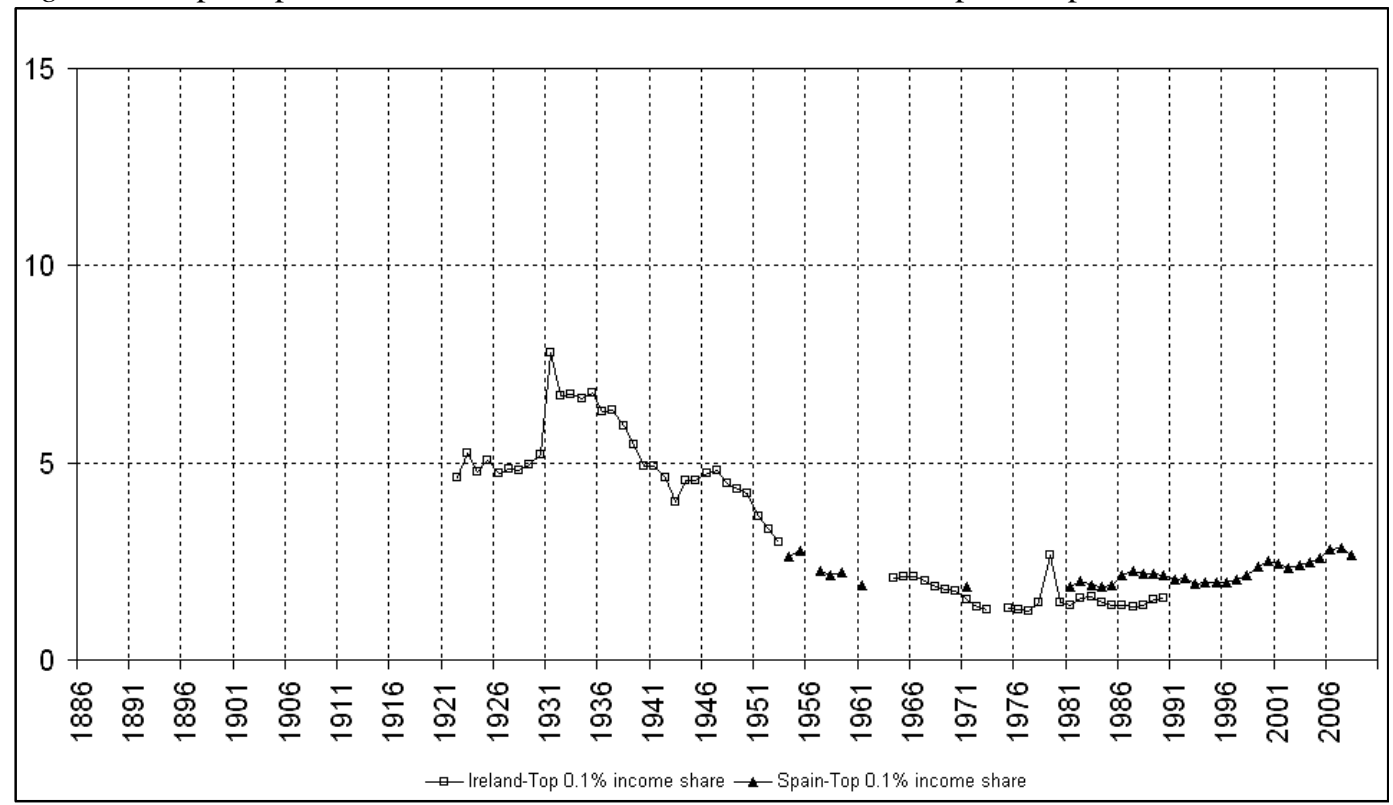

Source: Alvaredo et al. (2012) 
Figure $2 e$ Top 0.1 percent share in national income in Japan and Sweden, in percent

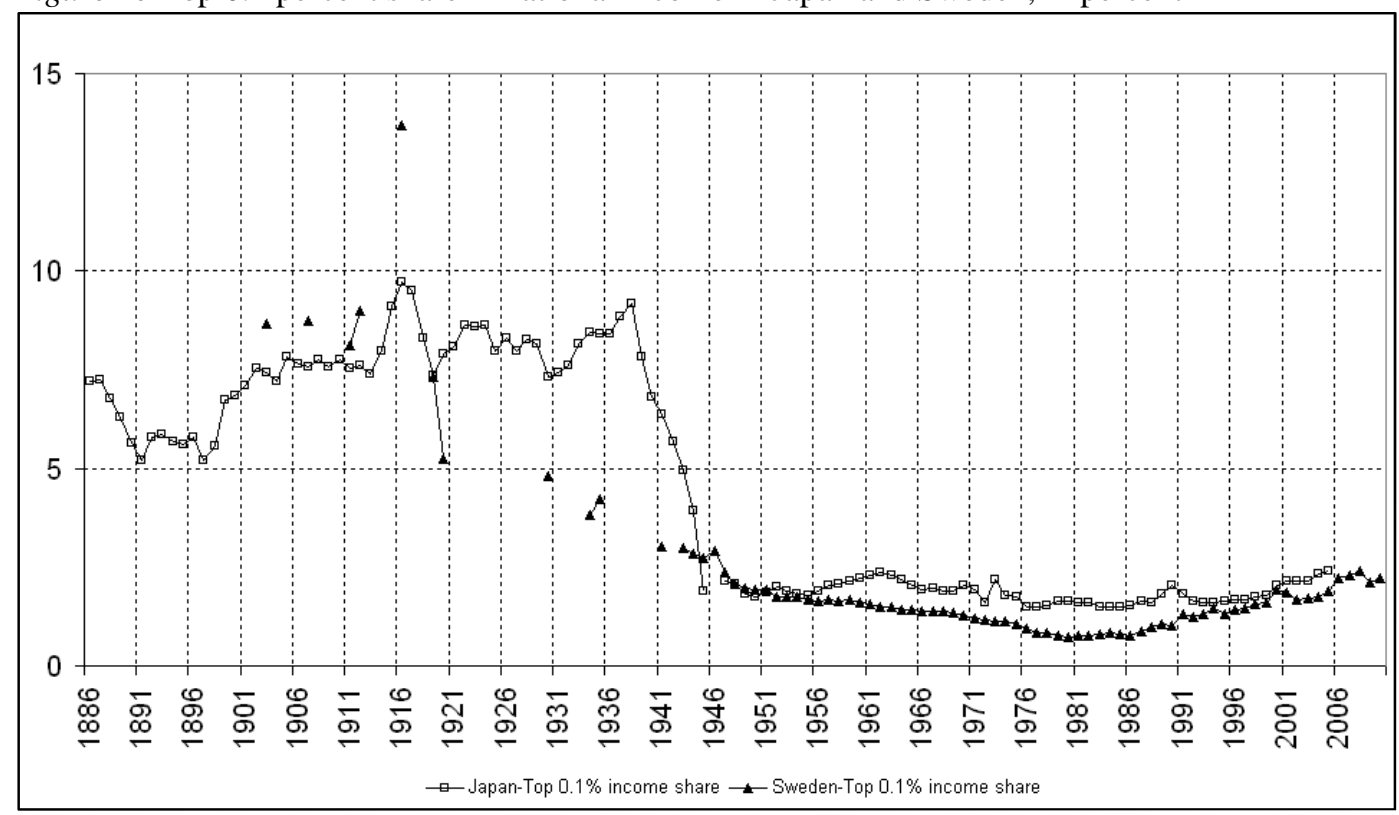

Source: Alvaredo et al. (2012)

If we take a look at the composition of top incomes, we find that the increase in the income share of the top 0.1 percent in the US has mainly been driven by an increase in top salaries (including wages and salaries, bonuses, exercised stock options and pensions) since the 1970s, and since the mid-1980s also in entrepreneurial income (Figure 3a). The share of capital income (interest, dividends, rents.) in the top 0.1 percent incomes decreased until the early 1990s and has remained roughly constant since then. Remuneration of top management ("working rich") has therefore contributed significantly, but not exclusively, to rising inequality in the US from the early 1980s until 2006. The decomposition of top incomes is only provided for a few countries in the dataset by Alvaredo et al. (2012). Out of these, the "working rich" phenomenon can also be found in Spain (Figure 3b), where the share of top management salaries in top 0.1 income has seen a rising trend from the early 1980 s until the early 2000 s, and in the Netherlands (Figure 3c) where such an increase could be observed in the course of the 1990s. In Italy (Figure 3d) we only find a slight increasing tendency since the early 1980s and in France (Figure 3e) there has not been such an increase at all.

In certain years top management salaries have contributed more than 50 percent to the income of the top 0.1 percent income share in the US and Spain and more than 60 percent in the Netherlands. In Germany, however, the main income of the top 0.1 percent income share is derived mainly from business activity (64.1 percent in 1992, 58.5 percent in 2003) and capital 
income (20.9 percent in 1992, 19.2 percent in 2003), with a decreasing trend each (Bach, Corneo, and Steiner 2009). Top management salaries have played a minor role. However, their share has increased from 15 percent in 1992 to 22.4 percent in 2003. Therefore, the "working rich" phenomenon seems to arise in Germany as well.

Figure 3a Composition of top 0.1 percent income, US, 1950-2010

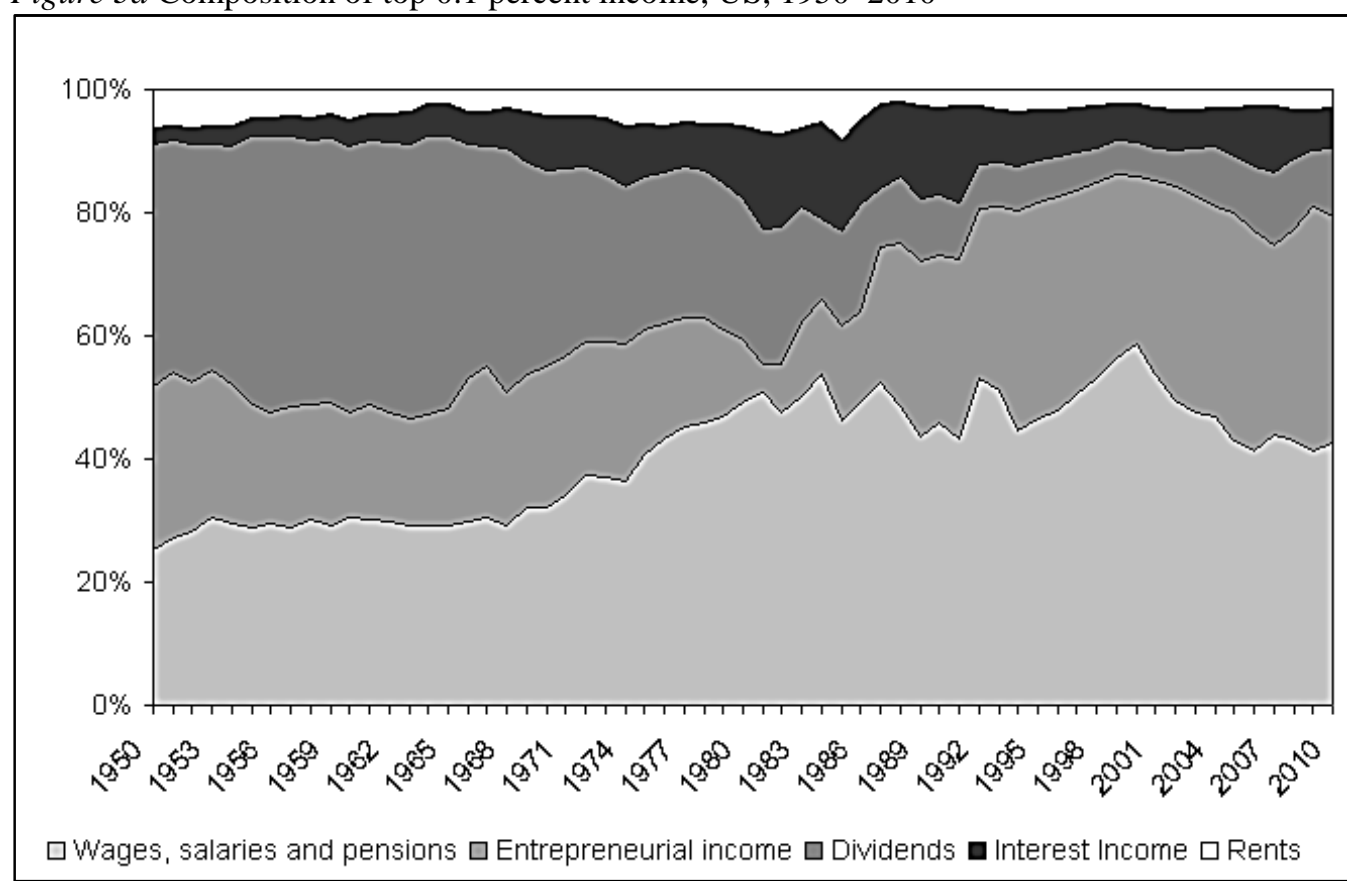

Source: Alvaredo et al. (2012)

Figure $3 b$ Composition of top 0.1 percent income, Spain, 1981-2008

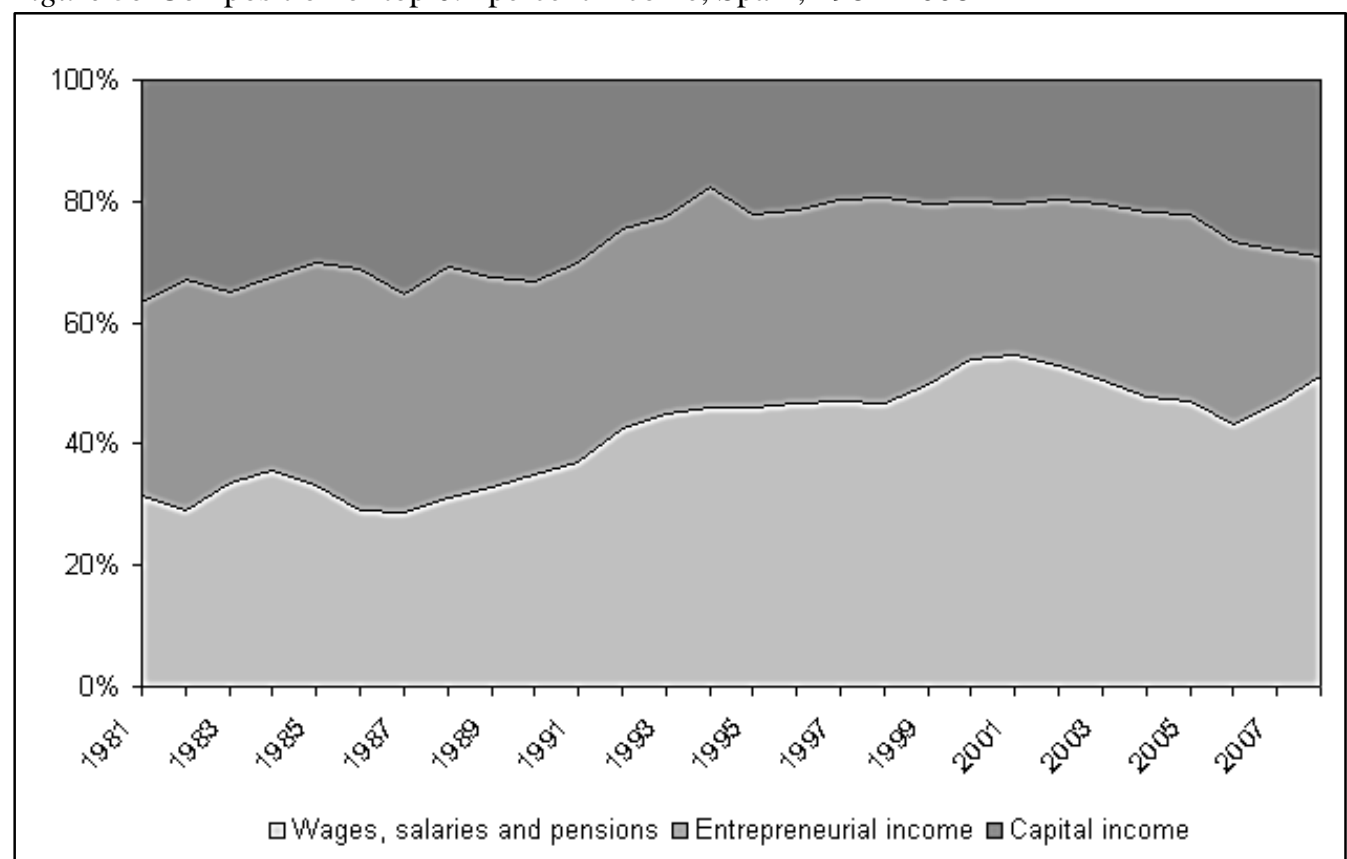

Source: Alvaredo et al. (2012) 
Figure 3c Composition of top 0.1 percent income, the Netherlands, 1970-1999

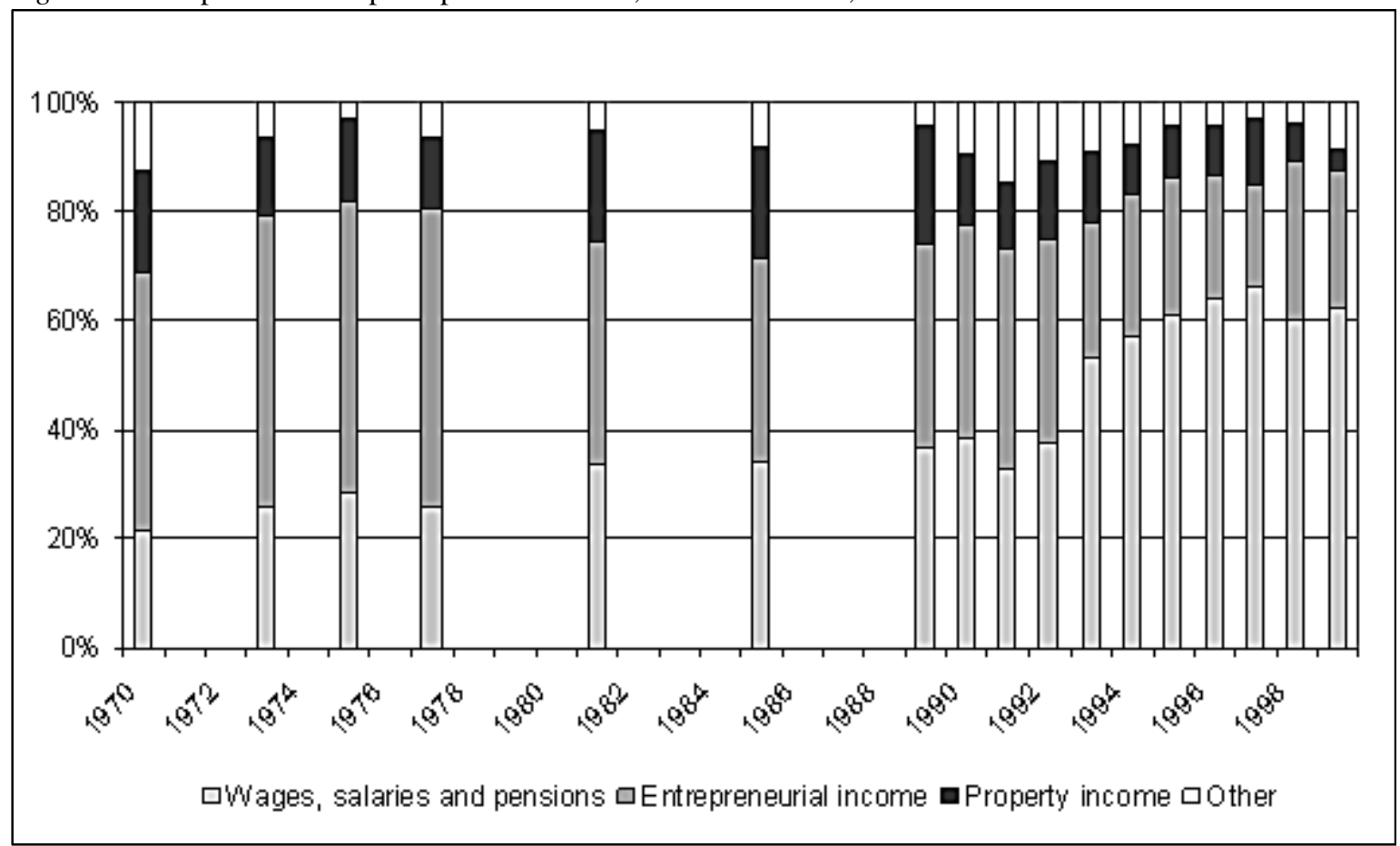

Source: Alvaredo et al. (2012)

Figure $3 d$ Composition of top 0.1 percent income, Italy, 1976-2008

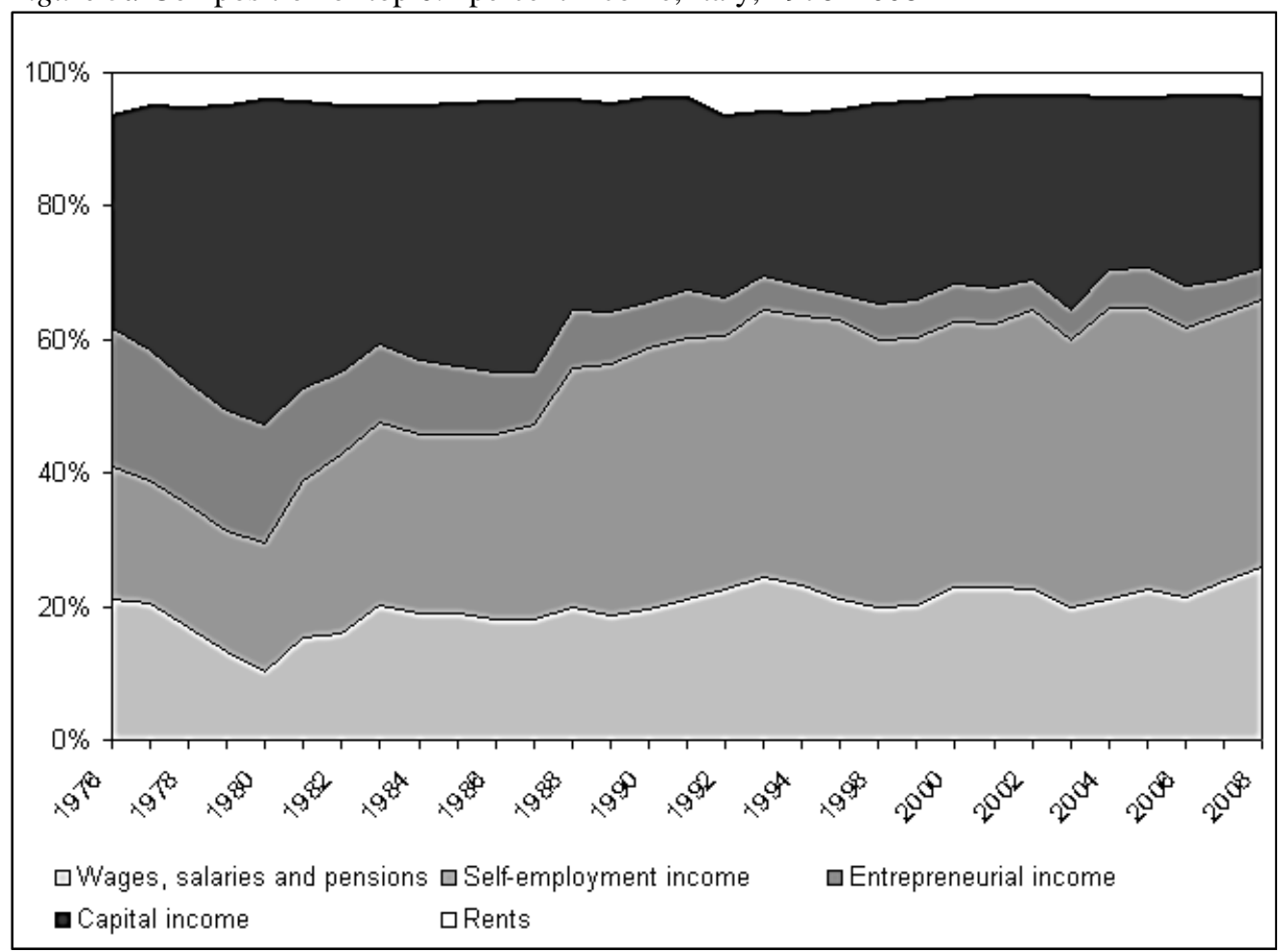

Source: Alvaredo et al. (2012) 
Figure 3e Composition of top 0.1 percent income, France, 1950-2005

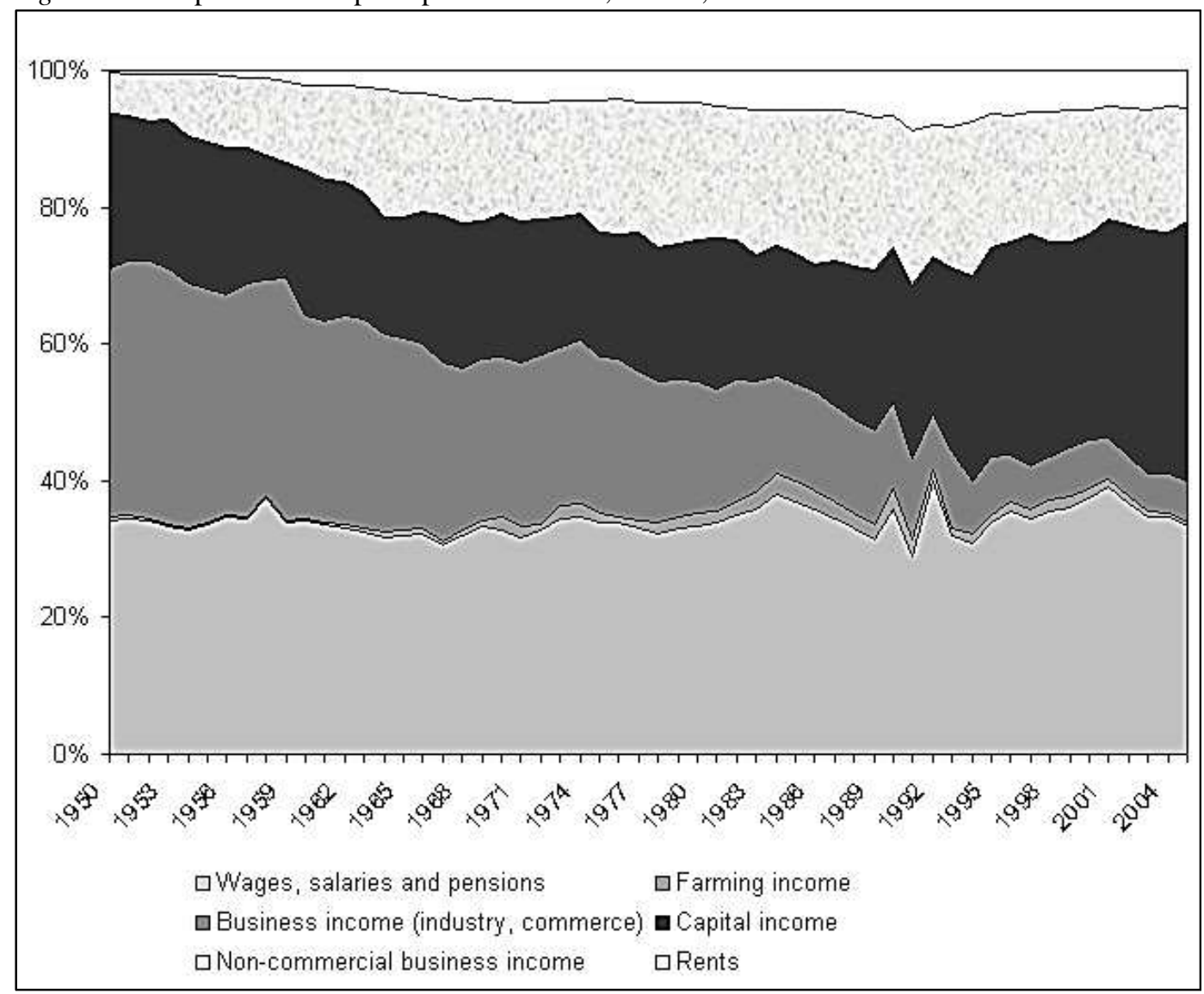

Source: Alvaredo et al. (2012)

Since top management salaries are part of compensation of employees in the national accounts and are thus included in the wage share considered above, the increase in top management salaries in the period of neo-liberalism and financialization has dampened the fall in the measured wage share since the early 1980s. Excluding top management salaries from the wage share would therefore give an even more pronounced fall in the share of "ordinary labor," in particular so in the US, Spain, and the Netherlands, where top management salaries are a major part of top incomes, but also in the other countries to a lesser extent. This has already been shown by Buchele and Christiansen (2007) and Glyn (2009) for the US and Dünhaupt (2011) for Germany and the US.

In the following section we will address the causes for the change in functional income distribution or in factor shares. ${ }^{9}$ On the one hand, the analysis of factor shares provides the link

\footnotetext{
${ }^{9}$ Empirical support for the contribution of financialization to increasing personal/household inequality and to rising top incomes have been presented by Tomaskovic-Devey and Lin (2011), applying the ratio of financial receipts (interest, dividends, and capital gains) to business receipts of non-financial industries as a proxy for
} 
between incomes at the macroeconomic or the national accounting level and incomes at the level of the household, thus helping to understand the development of inequality in personal distribution, and providing an indicator of the relative economic power of different groups, according to Atkinson (2009). On the other hand, the analysis of functional income distribution allows for a straightforward integration of changes in distribution into a macroeconomic modeling framework - as the Kaleckian approach to distribution and growth has shown, in particular, we would like to add.

\section{FINANCIALISATION AND CHANGES IN FUNCTIONAL DISTRIBUTION: POTENTIAL CHANNELS OF INFLUENCE}

In order to discuss the long-run effects of neo-liberalism and financialization on functional income distribution, we start with the Kaleckian approach to the determination of income shares (Kalecki 1954, pp. 11-41; 1971, pp. 43-77). According to Kalecki, functional income distribution in the industrial sector of the economy is determined by mark-up pricing of firms in incompletely competitive markets (monopoly, oligopoly, monopolistic competition, etc.). Whereas in the primary sector (agriculture, fishing, mining) with inelastic supply in the short run, changes in demand cause changes in prices, in the industrial sector changes in demand trigger changes in output and thus the rate of capacity utilization with prices being more or less rigid. The rate of capacity utilization therefore becomes endogenous in the Kaleckian models of distribution and growth focusing on industrial economies, both in the short run and in the long run. ${ }^{10}$ Since we are mostly dealing with developed capitalist economies with dominant industrial and service sectors, we apply Kalecki's approach. In the labor-intensive service sector below full employment, supply can be considered to be a variable, too, and prices can be assumed to be set by means of marking up unit costs.

Post-Keynesians have proposed different cost plus pricing procedures: mark-up pricing, full cost or normal cost pricing, and target rate of return pricing. ${ }^{11}$ For the sake of simplicity, we start with Kalecki’s (1954, pp. 11-41; 1971, pp. 43-77) mark-up pricing approach. What follows is not meant to present a detailed and exact analysis of pricing procedures in certain

financialization, and by Zalewski and Whalen (2010), using the IMF Financial Index a as proxy.

${ }^{10}$ See Hein, Lavoie, and van Treeck $(2011,2012)$ for a discussion of the related problems.

${ }^{11}$ See Lavoie (1992, pp. 129-148) for a discussion of Post-Keynesian pricing theory. He shows that there is no fundamental difference between mark-up pricing, full cost pricing and target rate of return pricing. See also Gu and Lee (2012) for a short overview and Lee (1998) for a more detailed treatment. 
periods of development of modern capitalism, but rather to identify potential channels of influence of financialization on pricing and distribution in a stylized way. We are interested in the potential medium- to long-run effects of financialization on distribution, but less on the causes of short-run, cyclical fluctuations in prices and in functional income distribution. With Kalecki we assume that firms mark up marginal costs that are roughly constant up to full capacity output given by the available capital stock. This implies that the mark-up is applied to constant average variable costs. Unit variable costs are composed of unit direct labor costs and unit material costs. To the extent that raw materials and semi-finished products are imported from abroad, international trade is also included in our model.

In this approach, the mark-up has to cover overhead costs, i.e., depreciation of fixed capital and in particular salaries of overhead labor, on the one hand, and firms' gross profits, i.e., interest and dividend payments as well as retained profits, on the other hand. As will be seen below, this approach is thus well suited to take the explosion of top management salaries observed in the US and other countries into account. With a given mark-up and constant unit variable costs up to full capacity output, gross and also retained unit profits will vary procyclically, because unit overhead costs will move counter-cyclically, i.e., will fall (rise) with fixed overhead costs spreading over increasing (decreasing) output.

For a vertically integrated domestic industrial or service sector $\mathrm{j}$, which uses fixed capital, labor and imported raw materials and semi-finished goods as inputs, we get the following pricing equation:

$$
\mathrm{p}_{\mathrm{j}}=\left(1+\mathrm{m}_{\mathrm{j}}\right)\left(\mathrm{wa}_{\mathrm{j}}+\mathrm{p}_{\mathrm{f}} \mathrm{e} \mu_{\mathrm{j}}\right), \quad \mathrm{m}>0,
$$

with $p_{j}$ denoting the output price in sector $j, m_{j}$ the mark-up, $w$ the nominal wage rate, $a_{j}$ the labor-output ratio, $\mathrm{p}_{\mathrm{f}}$ the unit price of imported material or semi-finished products in foreign currency, e the exchange rate, and $\mu_{\mathrm{j}}$ imported materials or semi-finished inputs per unit of output. Since the relationship between unit material costs and unit labor costs $\left(\mathrm{z}_{\mathrm{j}}\right)$ is given by:

$$
z_{j}=\left(\frac{p_{f} e \mu_{j}}{w a_{j}}\right),
$$

the price equation can also be written as:

$$
\mathrm{p}_{\mathrm{j}}=\left(1+\mathrm{m}_{\mathrm{i}}\right)\left[\mathrm{wa}_{\mathrm{i}}\left(1+\frac{\mathrm{p}_{\mathrm{f}} \mathrm{e} \mu_{\mathrm{i}}}{\mathrm{wa}_{\mathrm{j}}}\right)\right]=\left(1+\mathrm{m}_{\mathrm{i}}\right)\left[\mathrm{wa}_{\mathrm{i}}\left(1+\mathrm{z}_{\mathrm{j}}\right)\right] .
$$


The gross profit share $\left(\mathrm{h}_{\mathrm{j}}\right)$, including overhead costs and thus also management salaries, in gross value added of sector $\mathrm{j}$ is given by:

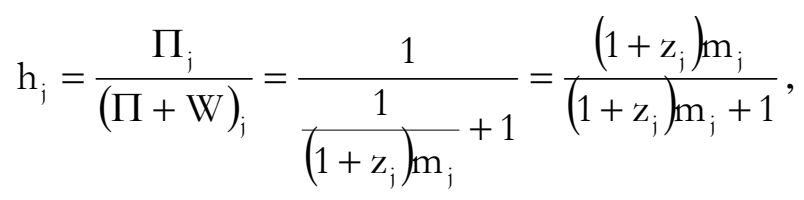

with $\Pi$ denoting gross profits including overhead costs and $\mathrm{W}$ representing wages for direct labor. For the corresponding share of wages for direct labor in gross value added $\left(1-\mathrm{h}_{\mathrm{j}}\right)$, we obtain:

$$
(1-h)_{j}=\frac{W_{i}}{(\Pi+W)_{j}}=\frac{1}{\left(1+z_{j}\right) m_{j}+1} .
$$

The gross profit share (h) including overhead costs for the economy as a whole is given by the weighted average of the sectoral profit shares, the wage share of direct labor $(\omega=1-h)$ for the economy by the weighted average of the sectoral wage shares:

$$
\begin{aligned}
& h=\frac{\Pi}{(\Pi+W)}=\frac{1}{\frac{1}{(1+z) m}+1}=\frac{(1+z) m}{(1+z) m+1}, \\
& 1-h=\frac{W}{(\Pi+W)}=\frac{1}{(1+z) m+1} .
\end{aligned}
$$

Functional income distribution is thus determined by the mark-up in pricing of firms, by the relationship of unit material costs to unit labor costs, and by the sectoral composition of the economy. With constant technical conditions of production (constant a and $\mu$ ), an increasing gross profit share including overhead costs (a decreasing wage share of direct labor) can either be caused by rising mark-ups, a falling nominal wage rate, rising prices of imported materials or semi-finished goods in foreign currency, a depreciation of the domestic currency (thus a rising exchange rate), and/or a change in the sectoral composition of the economy in favor of high profit share sectors.

Before discussing the potential channels of influence of financialization and neoliberalism on functional income distribution, the determinants of the mark-up have to be examined more closely. According to Kalecki (1954, pp. 17-18; 1971, pp. 49-52) the mark-up, or what he calls the "degree of monopoly," has several determinants.

First, the mark-up is positively related to the degree of concentration within the respective industry or sector. A high degree of concentration within an industry makes price 
leadership by the most important firms, tacit agreements, or more or less formal cartels more likely. Second, the mark-up is negatively related to the relevance of price competition relative to other forms of competition (product differentiation, marketing, etc.). We summarize these two determinants as the "degree of price competition among firms in the goods market." These determinants of the mark-up have been highlighted, in particular, in the works of Steindl (1976) and Baran and Sweezy (1966) focusing on the tendencies toward "monopoly capital."12 They have been integrated into the modern Kaleckian/Steindlian distribution and growth models starting with the works by Rowthorn (1981) and Dutt (1984).

Third, Kalecki claims that the power of trade unions has an adverse effect on the markup. In a kind of strategic game, firms anticipate that strong trade unions will demand higher wages if the mark-up and hence profits exceed "reasonable" or "conventional" levels, so that the high mark-up can only be sustained at the expense of ever rising prices and finally a loss of competiveness of the firm. ${ }^{13}$ This will induce firms to constrain the mark-up in the first place. Starting with Rowthorn's (1977) contribution to the Post-Keynesian literature, the effect of trade union bargaining power has been integrated into conflict claims inflation models, in which workers/trade unions and firms have conflicting and potentially inconsistent income claims generating inflation, on the one hand, and affecting income distribution, on the other hand (see for instance Lavoie 1992, pp. 372-421; Hein and Stockhammer 2010).

Fourth, Kalecki argues that overhead costs may affect the degree of monopoly and hence the mark-up. Since a rise in overhead costs squeezes gross profits, "there may arise a tacit agreement among the firms of an industry to 'protect' profits, and consequently to increase prices in relation to unit prime costs" (Kalecki 1954, p. 17). ${ }^{14}$ From the perspective of the firm, interest payments on debt are also part of overhead costs, and thus the idea of an interest rate or interest payments elastic mark-up has been introduced into Kaleckian models of distribution and

\footnotetext{
${ }^{12}$ Also Sylos-Labini's (1969) idea of entry-preventing-pricing is related to price competition among firms in the goods market as a determinant for the mark-up. Sylos-Labini (1969) argues that with fixed costs digression the large incumbent firm within a sector will set prices and hence mark-ups such that entry by smaller firms with a lower level of output and thus higher unit total costs will be deterred.

${ }^{13}$ See also Kalecki's (1971, pp. 156-164) chapter on "Class struggle and the distribution of income," where he argues that trade-union power "manifests itself in the scale of wage rises demanded and achieved" (Kalecki 1971, p. 162). Part of this will be shifted to prices and hence to consumers, another part will be absorbed by a lower mark-up. Sylos-Labini (1979) has presented a rationale for this partial adjustment of prices to changes in unit labor costs in an oligopolistic pricing framework for a specific industry characterized by uniform output prices, uniform wage rates but differentials in labor productivity and hence mark-ups.

${ }^{14}$ However, Kalecki (1954, p. 18) adds: "The degree of monopoly may, but need not necessarily, increase as a result of a rise in overheads relative to prime costs."
} 
growth (Lavoie 1993; Hein 2006, 2007, 2008, pp. 102-123). ${ }^{15}$ A permanent increase in interest rates (or interest payments) would thus induce firms on average to increase the mark-up in order to survive. Recently, this idea has been further extended arguing that from the perspective of the management of the firm, dividend payments are as well a kind of overhead obligation. A permanent increase of dividend payments could therefore induce management to recover this drain of funds for real investment or other purposes by means of increasing the mark-up, either by raising prices or forcing down unit labor costs if market conditions and relative bargaining power of firms and labor unions allow for it (Hein 2010a, 2010b; Hein and van Treeck 2010a, 2010b).

Making the mark-up elastic with respect to different types of overheads and gross profit claims means that firms need to have a notion of normal or long-run average levels of output or rates of utilization of capacity given by the capital stock, because unit overhead costs decrease with output. The mark-up approach becomes thus equivalent to a target rate of return approach (Lavoie 1992, p. 135), and the mark-up in equation (1) can be understood as being determined by a target rate of return at long-run average levels of output or rates of capacity utilization. In the early target rate of return approaches by Eichner (1976), Harcourt and Kenyon (1976) and Wood (1975), it was assumed that the mark-up set by the firm is determined by the required internal means of finance for real investment purposes-under the conditions of incomplete credit markets characterized by asymmetric information, which do not allow firms to borrow without having own means of finance, according to Kalecki's (1937) "principle of increasing risk." Therefore, in these approaches, it was growth expectations of firms that determine the target rate of return and thus the mark-up. Recently, this approach has been extended by allowing for different target rates of returns by different stakeholder groups within a firm. Lavoie (2002) presented a model of target rate of return pricing with different target rates of workers and firms, generating conflict inflation and an endogenous normal rate of capacity utilization. Dallery and van Treeck (2011) have included shareholders and their target rate of return into the model and have derived different outcomes depending on the relative powers of each group. Their model allows for the analysis of the effects of various features of financialization, in particular the effects of the dominance of shareholders over other groups

\footnotetext{
${ }^{15}$ This approach has been inspired by the treatment of interest payments as part of the costs of the firm in the neoRicardian monetary theory of distribution (Panico 1985; Pivetti 1985, 1991) which pick up Sraffa's (1960, p. 33) idea of closing the degree of freedom of a system of prices of production by the interest rate.
} 
imposing their target rate of return, or "financial norm" (Boyer 2000), on the firm as a whole. Taking these recent extensions into account, the mark-up in equation (1) can be seen as reflecting the target rate of return as an outcome of distribution struggle within the firm, at a long-run average rate of capacity utilization, which itself is an endogenous outcome of the distribution struggle, on the one hand, and interacting with aggregate demand in the goods market, on the other hand.

Table 2 Financialization and the gross profit share - a Kaleckian perspective

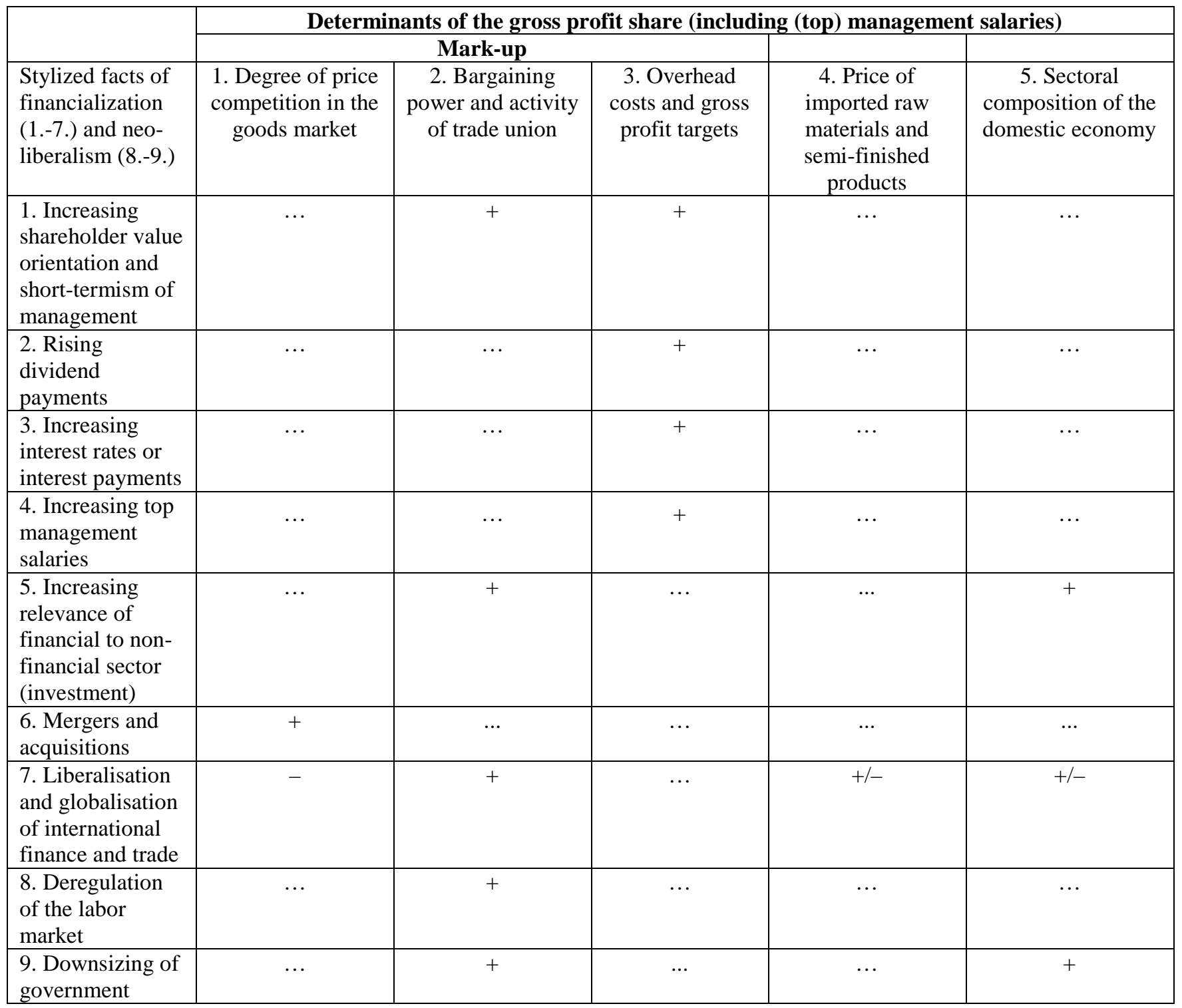

Notes: + positive effect on the gross profit share, - negative effect on the gross profit share, $\ldots$ no direct effect on the gross profit share 
Having so far identified the main channels of influence on the labor income share of direct labor, respectively on the gross profit share including management salaries, we can now discuss the potential effects of financialization and neo-liberalism on functional income distribution via the channels identified above and summarize these potential channels in Table 2. We consider the three determinants of the mark-up: the degree of price competition in the goods market, bargaining power and activity of trade unions in the labor market, and overhead costs and gross profit targets. Furthermore, we consider the prices of imported raw materials and semi-finished goods (in relation to direct labor costs) and the sectoral composition of the domestic economy. From the enormous recent literature on financialization, already referred to in the introduction to this paper, we can derive the following seven "stylized facts" that may have exerted a direct impact on income distribution, if we follow the Kaleckian approach: increasing shareholder value orientation and increasing short-termism of management; rising dividend payments; increasing interest rates and interest payments, in particular in the 1980s; increasing top management salaries; increasing importance of financial as compared to real investment and hence the rise of the financial sector relative to the non-financial sector; hostile takeovers, mergers, and acquisitions; and liberalization and globalization of international finance and trade. We have added two further developments since the early 1980s that might have affected functional income distribution, and which are part of neo-liberalism: deregulation of the labor market and pressure on downsizing of the share of government activity in real GDP, of government intervention in the private sector of the economy, and of government aggregate demand management. Table 2 indicates the potential effects—positive or negative - these developments have on the gross profit share, including top management salaries, via the channels proposed by the Kaleckian theory of distribution. In the following section, we discuss the relevance of these potential effects on the determinants of income distribution and check whether the related empirical literature provides support for or is at least in line with these channels of influence.

\section{EVIDENCE}

The degree of price competition in the goods market is affected in an ambiguous way by the stylized facts of financialization and neo-liberalism, so that the overall effect remains unclear, a priori (Table 2). Hostile takeovers, mergers, and acquisitions may increase industrial 
concentration and, ceteris paribus, allow for higher mark-ups, whereas liberalization and globalization of international trade and finance obviously increase the degree of price competition and thus impose a downward pressure on the mark-up. The overall effect thus remains unclear. A similar result holds for the prices of imported raw materials and semifinished goods (relative to wage costs) as a determinant of the profit share. They may be affected by globalization and liberalization of international trade and finance, but in an ambiguous way. Whereas prices of labor intensive reproducible semi-finished goods have a tendency to decline due to increased international competition and relocation of production to low wage regions, prices of non-reproducible raw materials, in particular energy, have a tendency to rise due to the industrialization of China and India and the increase in world demand, in particular. The overall effect is again unclear. In what follows, we will therefore focus on the remaining three channels in Table 2, through which income shares seem to be affected by financialization and neo-liberalism in a more or less unambiguous way. We will treat them in reverse order.

\section{Sectoral Composition of the Domestic Economy}

The sectoral composition of the economy may be affected by an increasing share of the financial sector in value added as compared to the non-financial sector, on the one hand, and by downsizing government activity in GDP, on the other hand. The effect of the latter is obvious because in the national accounts the government sector is a "non-profit" sector; government owned corporations are part of the corporate sector. And even if we included top management salaries in the profit share from the national accounts, this should only have a minor effect for the government sector as compared to the private sectors of the economy in which these salaries usually exceed those in the public sector. Therefore, to the extent that financialization and neoliberalism are associated with downsizing government, this will, ceteris paribus, reduce the economy-wide wage share and increase the profit share. An increasing share of value added of financial corporations relative to the non-financial corporations will push up the economy-wide gross profit share, too, if the sectoral wage share in the financial sector falls short of that in the non-financial sector. In a decomposition study for Germany (1980-2008) and the US (19702008), Dünhaupt (2012) shows that in these two countries this has indeed been the case: In the US, the wage share according to the national accounts, thus including top management salaries, has been fluctuating around slightly less than 75 percent in the non-financial corporate sector 
and around 65 percent in the financial corporate sector, each without a clear tendency to fall. It has been the increase in the share of the financial sector in value added of the corporate sector that has caused the wage share in the US corporate sector to fall. In Germany, where the share of the financial sector in value added of the corporate sector has only slightly increased in the 2000s, the wage share in the financial sector has been fluctuating around 70 percent without any long-run downward or upward tendency, whereas the wage share in the non-financial sector, having been around 77 percent until the mid-1990s, has shown a considerable downward tendency since then and has fallen to the level of the financial corporate sector. Therefore, in Germany, the fall in the wage share in the corporate sector has been dominated by the falling wage share in the non-financial corporations, with the sectoral shift toward the financial sector contributing since the early 2000s.

\section{Overhead Costs and Gross Profit Targets}

With regard to overhead costs and gross profit targets, we have already discussed increasing top management salaries, showing how significant this development has been for top incomes in the US, but also recently in other countries like Spain and the Netherlands, and to a lesser degree in Germany and Italy. Excluding top management salaries from the wage share taken from the national accounts would therefore have made the latter fall even more, as the studies referred to in Section 2 have shown, which means that there is at least a correlation of a rising share of top management salaries in GDP and a falling tendency of the share of direct labor. TomaskovicDevey, and Lin (2011) applying a panel error correction model to 35-40 non-financial, nonagricultural industries of the private sector of the US economy (1970-2008), in order to estimate the effects of financialization on income distribution, supply econometric evidence for a causal relationship. Using the ratio of financial receipts (interest, dividends, and capital gains) to business receipts as a proxy for financialization, the authors find that an increasing degree of financialization is associated with a long-run increase in the corporate officers' share of compensation, and a fall in the labor income share, lending some support to the overhead costs and gross profits targets channel through which financialization affects income shares.

Focusing next on interest and dividend payments, we find the following results from the literature. Studying the development of the profit rate of non-financial corporations in France and the US (1960-2001), Dumenil and Levy (2005) have found that the rise in this profit rate since the early 1980 s has been mainly due to the rise in net real interest payments. Excluding 
these payments from profits, the profit rate of the non-financial corporate sector has remained constant in France and has increased only slightly in the US. ${ }^{16}$ Therefore, rising interest payments have had to be paid for by a reduction in the labor income share and it has thus been mainly the rentiers class which has benefited from redistribution at the expense of labor. In a more general study on 29 OECD countries (1960-2000) focusing on the development of the share of rentiers' income in GDP, Epstein and Power (2003) confirm the results by Dumenil and Levy (2005). They show that the share of rentiers' income in GDP increased at the expense of the wage share in most countries during the 1980s, remaining on the high level through the 1990s. In their study, rentiers' income is defined as the sum of profits of the financial sector plus interest income of the non-financial sector and households. Since nominal interest payments also compensate for capital losses due to inflation, Epstein and Jayadev (2005) have extended the analysis for 15 OECD countries (1960-2000), correcting the share of rentiers' income in GDP for inflation. Applying this method, they mainly confirm the earlier results by Epstein and Power (2003). These studies, however, only partially cover the distributive effects of financialization because they do not include dividend payments of non-financial corporations to private households in their definition of rentiers' income.

Dünhaupt (2012) has therefore redefined rentiers' income as net property income of private households, including thus net interest and net dividends received, and she has examined the development of the rentiers' share in net national income and of its components for Germany (1980-2008) and the US (1970-2008). For the US, she finds an increase in the rentiers' share in the early 1980s, which then remains roughly constant over the next 2.5 decades, and a corresponding decline in the wage share, whereas the share of retained earnings shows no marked trend. The decomposition of the rentiers' share reveals that the spike in the early 1980s was mainly driven by net interest income and that since the late 1980s, net dividend income has increased its share tremendously. In Germany, the rentiers' share has increased continuously since the early 1990s with a corresponding fall in the wage share, whereas the share of retained earnings shows marked fluctuations but no trend. The increase in the rentiers share has almost exclusively been driven by an increase in the share of dividend income.

\footnotetext{
${ }^{16}$ The profit-rate of the financial sector in the US, however, has increased significantly since the early 1980s, exceeding the profit rate of the non-financial sector by a considerable amount since then (Dumenil and Levy 2004a).
} 
Econometric evidence on the effects of rentiers' income claims on the wage share or the gross profit share is rather limited and is focused on the effects of interest rates or interest payments. Marterbauer and Walterskirchen (2002) have estimated the determinants of the adjusted wage share for the overall economy in Austria, Germany, Denmark, Finland, Ireland, Italy, the Netherlands, and Sweden (1970-2000). They find significant effects with the expected sign almost uniformly for each of the countries for GDP growth indicating the effect of the trade cycle, the unemployment rate representing trade union bargaining power, and inflation capturing the effect of changes in prices of imported raw materials and semi-finished products. For Austria, they also include the real long-term interest rate, which is taken to reflect rentiers' income claims. Although the variable shows the expected sign, it is not statistically significant.

Argitis and Pitelis (2001) obtained for the non-financial corporate sector in the US and the UK (1965-1997) that the nominal interest rate negatively affects the share of industrial profits in gross value added of the non-financial corporate sector in both countries. Further determinants of the share of industrial profits are nominal wages and the bargaining power of labor unions, measured by unemployment and strike intensity. Therefore, according to these results, a rise in the interest rate does not seem to affect the mark-up and thus does not harm the wage share directly, but rather seems to compress industrial profits. However, if rising interest rates are accompanied by weakened bargaining power of labor unions and lower wage demands, redistribution will take place at the expense of labor income, according to the results by Argitis and Pitelis (2001).

Marterbauer and Walterskirchen (2002) and Argitis and Pitelis (2001) have thus found no significant direct impact of overhead costs associated with financialization on the wage share or the gross profit share. However, they have only introduced real or nominal interest rates into their regressions and have not controlled for indebtedness of the business or corporate sector. ${ }^{17}$ Hein and Schoder (2011) have therefore included net interest payments of the non-financial business sector in relation to the nominal capital stock of this sector into their estimations of a profit share function for the total economy for Germany and the US (1960-2007). ${ }^{18}$ The following control variables have been applied: the unemployment rate indicating the relative

\footnotetext{
${ }^{17}$ Hein and Ochsen (2003) also report that they have not found any significant effect of the interest rate in their estimations of a profit share functions for France, Germany, the UK, and the US from the early 1960s to the mid1990s.

${ }^{18}$ The profit share is the net operating surplus of the total economy adjusted for the labor income of the selfemployed related to the net value added.
} 
powers of worker and firms in the distribution struggle, consumer price inflation indicating exogenous price shocks, and the growth rate of real net domestic income as an indicator for demand affecting the short-run maneuvering room of firms for price setting. They find a highly significant and strong effect of net interest costs on the profit share, thus confirming the notion of an interest payment's elastic mark-up affecting distribution between capital and labor. Unemployment has a positive effect on the profit share in the US, but no effect in Germany. Inflation shocks affect the profit share negatively in both countries. Hence, on average, trade unions were strong enough to compensate for inflation induced losses in the real wage position of workers. Aggregate demand had a short-run positive but long-run negative impact on the profit share in both countries.

Taken together, there seems to be some statistical evidence that rising overhead costs and rising profit claims of shareholders correlate with a falling wage share. Econometrically, however, it seems to be difficult to disentangle these effects and further studies on these issues seem to be required. Hein and Schoder (2011) and Tomaskovic-Devey and Lin (2011) are the only recent studies to our knowledge which supply statistically significant results for the overhead costs and gross profit targets channel through which financialization has affected income shares. All the econometric studies referred to so far, however, find significant effects of the last channel of influence of financialization on the profit share to be reviewed: bargaining power and activity of trade unions.

\section{Bargaining Power and Activity of Trade Unions}

Trade union bargaining power and activity can be assumed to have been affected by the following features of financialization and the neo-liberal period since the early 1980s. First, shareholder value orientation and increasing short-termism of management has weakened trade unions by replacing the "retain and invest" strategy of the Fordist era with a "downsize and distribute" strategy (Lazonick and O'Sullivan 2000) aiming at high share prices, and by increasing the importance of profits from financial investments (interest, dividends, realized capital gains) as compared to real investment for the management of non-financial corporations. Second, the increasing importance of the financial as compared to the non-financial sector can be supposed to have weakened trade unions because they have been traditionally stronger in the non-financial sector in many countries, particularly in the industrial sector of the private economy and in the public sector. Similar effects could therefore be found when downsizing the 
government sector. Related to this, the abandonment of Keynesian demand management policies aimed at low unemployment and their replacement with Monetarist supply side policies aimed at low inflation, drastically increased unemployment in the early 1980s. Furthermore, deregulation of the labor markets since the early 1980s has been especially aimed at undermining the bargaining power of trade unions, since this has been assumed to be an important factor for the non-accelerating inflation rate of unemployment (NAIRU) in mainstream theory and politics (Stockhammer 2004, Chapter 3). Liberalization and globalization of international trade and international finance has increased competition among workers through the "threat effect" of firms to outsource and relocate production. Since trade unions are still predominantly organized at the national levels, outsourcing and relocation threats have also contributed to weakened trade union bargaining power.

Recent panel estimations by the International Monetary Fund (IMF 2007a) for 18 OECD countries (1983-2002), and by the European Commission (2007) for 13 OECD countries (19832002) have found that skill-biased technological change is the most important variable affecting the labor income share, taking Information Communications Technology (ICT) use and/or capital labor ratios as proxies. Globalization, proxied by relative export and import prices, offshoring, immigration, and/or openness, also contributes, but labor market institutionsrepresenting trade union bargaining power-have little importance for functional income distribution, taking the tax wedge, unemployment benefits, union density, minimum wages, and employment protection legislation as indicators. From the Kaleckian perspective applied in this paper, it is not clear why skill-biased technical change should affect the overall wage share or labor income share as derived from the national accounts in the negative-we would rather expect a higher degree of wage dispersion if the recent type of technological change, demanding a higher degree of qualification and education, improved the bargaining position for high-skilled labor but weakened the position of the low-skilled. ${ }^{19}$

Stockhammer (2009) has checked the robustness of the results of the European Commission (2007) and the IMF (2007a) for a sample of 15 countries (13 EU countries, Japan, and the US, 1982-2003), finding that they are not robust at all and suffer from serious econometric problems. According to his results, the effect of technological change, indicated by ICT services and capital-labor ratios, often turns statistically insignificant. Globalization,

\footnotetext{
${ }^{19}$ It is therefore less surprising that, examining the determinants of personal income dispersion, the IMF (2007b) finds that skill-biased technological change together with financial deepening have increased income inequality.
} 
however, has a robust effect. Extending the econometric model and estimating five years nonoverlapping averages gives statistically significant, strongly negative effects of the globalization of trade, measured by the relationship of imports plus exports to GDP, and of financial globalization, indicated by foreign assets and liabilities as a ratio of GDP, on the labor income share. Union density has a positive effect on the labor income share in non-Ghent countries. Therefore, Stockhammer (2009, p. 53) concludes: "Overall our findings support the view that income distribution has changed due to globalization in production and finance, [and] changes in the bargaining power between capital and labor rather than through technological change."

In a recent study on 16 OECD countries (1961-2005), Kristal (2010), using a panel Error Correction model, has supported the finding that the decline in workers' bargaining power explains most of the changes in the labor income share observed in these countries. Macroeconomic factors (productivity growth, unemployment, and inflation) are used as control variables in the estimation. The concept of workers' bargaining power applied for the determination of the labor income share (including the labor income of the self-employed) of national income, is a broad concept. It includes the economic dimension (unionization and strike activity), the political dimension (government civilian spending), workers' bargaining power in the global sphere (southern imports and foreign direct investments), and the intra-class sphere (bargaining centralization) of bargaining power. Fully in line with our expectations, but without linking the results to financialization, the author concludes:

The declining trend of labor's share since the early 1980s is associated with deterioration of workers' organizational power resources in advanced capitalist countries. Unionization rates and levels of strike activity have fallen, government civilian spending has stagnated, and workers' collective action power to redistribute income in favor of labor has been severely weakened. Labor's capacity to influence state policies has also declined across countries, and governments' targets of full employment have been abandoned in favor of labor market flexibility and low inflation. The current decline in labor's share is also due to workers' lessening power in the global context due to integration of countries into international markets, which has caused an increase in imports from developing countries, cheap immigrant labor, and capital mobility. (Kristal 2010, p. 752)

Tomaskovic-Devey and Lin (2011), in their study on non-financial, non-agricultural US industries already referred to above, have explicitly estimated the effects of financialization on the labor income share, using the ratio of financial receipts (interest, dividends, and capital gains) to business receipts as a proxy for financialization. It is argued that this ratio is inversely related to workers' bargaining power because it indicates increasing shareholder value 
orientation and short-termism of management and an increasing relevance of financial investment as compared to investment in capital stock and human capital of the firm. Therefore, the authors provide some evidence for the bargaining power and activity of trade union channels through which financialization might affect income distribution. They find that an increased dependence on financial earnings of non-financial industries has a negative effect on the labor income share in the long run. The control variables applied have the following effects: Union density, the proportion of workers with a college degree, and the proportion of workers that are non-Hispanic white men are positively associated with the labor income share. Investment in computer technology, the degree of import penetration, and industrial concentration are negatively related with the labor income share.

\section{CONCLUSIONS}

In this paper we have examined a major channel through which financialization or financedominated capitalism affects macroeconomic performance: the distribution channel. We have started with an empirical overview of different dimensions of (re-)distribution in the period of finance-dominated capitalism since the early 1980s for 15 developed capitalist economies. We have found falling labor income shares and increasing inequality in the personal/household distribution of market incomes with only a few exceptions, increasing inequality in the personal/household distribution of disposable income in most of the countries, an increase in the income share of the very top incomes in particular in the US and the UK, but also in most of the other countries for which data is available, with rising top management salaries as one of the major driving forces. Since we consider the determination and the trends of functional distribution as the key to the understanding of these redistribution tendencies, we have outlined the Kaleckian approach to the determination of income shares in Section 3. In this section, we have also provided an attempt at integrating some "stylized facts" of financialization and neoliberalism into this approach: increasing shareholder value orientation and short-termism of management, rising dividend payments, increasing interest payments, increasing top management salaries, increasing relevance of the financial sector (and of financial investment) relative to the non-financial sector (and to non-financial investment), mergers and acquisitions, liberalization and globalization of international finance and trade, deregulation of the labor market, and pressures of downsizing government activity and interventions. In Section 4, we 
have reviewed the empirical and econometric literature, which supports or is in line with the channels through which financialization has affected functional income distribution from a Kaleckian perspective. We have found that there is some evidence that financialization and neoliberalism have contributed to the falling labor income share since the early 1980s through three main channels. First, the shift in the sectoral composition of the economy from the public sector and the non-financial business sector with high labor income shares towards the financial business sector with a lower labor income share has contributed to the fall in the labor income share for the economy as a whole. Second, the increase in management salaries as a part of overhead costs together with rising profit claims of the rentiers, i.e., rising interest and dividend payments of the corporate sector, have been associated with a falling labor income share. Third, financialization and neo-liberalism have weakened trade union bargaining power through several channels: increasing shareholder value orientation of management, the sectoral shifts away from the public sector and the non-financial business sector with stronger trade unions in many countries to the financial sector with weaker unions, deregulation of the labor market, and liberalization and globalization of international trade and finance. These developments have not only triggered falling labor income shares, but they should also have been conducive to increasing inequality of personal/household incomes as a major feature of finance-dominated capitalism. However, this relationship requires further examination. 


\section{REFERENCES}

Alvaredo, F., A. B. Atkinson, T. Piketty, and E. Saez. 2012. “The World Top Incomes Database." http://g-mond.parisschoolofeconomics.eu/topincomes.

Anselmann, C. and H. M. Krämer. 2012. "Completing the Bathtub? The Development of Top Incomes in Germany, 1907-2007." SOEPpapers on Multidisciplinary Panel Data Research, 451. Berlin: DIW.

Argitis, G. and C. Pitelis. 2001. "Monetary Policy and the Distribution of Income: Evidence for the United States and the United Kingdom." Journal of Post Keynesian Economics 23(4): 617-38.

Atkinson, A. B. 2009. "Factor Shares: The Principal Problem of Political Economy?" Oxford Review of Economic Policy 25(1): 3-16.

Atkinson, A. B., T. Piketty, and E. Saez. 2011. "Top Incomes in the Long Run of History." Journal of Economic Literature 49(1): 3-71.

Bach, S., G. Corneo, and V. Steiner. 2009. "From Bottom to Top: The Entire Distribution of Market Income in Germany, 1992-2003." Review of Income and Wealth 55(2): 303-30.

Baran, A. B. and P. M. Sweezy. 1966. Monopoly Capital. New York, NY: Monthly Review Press.

Bibow, J. 2008. "The International Monetary (Non-) Order and the 'Global Capital Flows Paradox."' In E. Hein, T. Niechoj, P. Spahn and A. Truger (Eds.), Finance-led Capitalism? Macroeconomic Effects of Changes in the Financial Sector. Marburg, Germany: Metropolis.

Boyer, R. 2000. Is a Finance-Led Growth Regime a Viable Alternative to Fordism? A Preliminary Analysis." Economy and Society 29: 111-45.

Buchele, R. and J. Christiansen. 2007. "Globalization and the Declining Share of Labor Income in the United States." Paper prepared for the $28^{\text {th }}$ International Working Party on Labor Market Segmentation, Aix-en-Provence, France, July 5-7. http://gesd.free.fr/paper419.pdf

Dallery, T. and T. van Treeck. 2011. "Conflicting Claims and Equilibrium Adjustment Processes in a Stock-Flow Consistent Macro Model." Review of Political Economy 23(2): 189-211.

Dew-Becker, I. and R. Gordon. 2005. "Where Did the Productivity Growth Go to? Inflation Dynamics and the Distribution of Income." Brooking Papers on Economic Activity 2: 67-125.

Dumenil, G. and D. Levy. 2004a. "The Real and Financial Components of Profitability (USA 1948-2000)." Review of Radical Political Economics 36(1): 82-110. 
- 2004b. "Neoliberal Income Trends. Wealth, Class and Ownership in the USA." New Left Review 30: 105-33.

- 2005. "Costs and Benefits of Neoliberalism: A Class Analysis." In G. A. Epstein (Ed.), Financialization and the World Economy. Cheltenham, UK: Edward Elgar.

Dünhaupt, P. 2011. "Financialization, Corporate Governance and Income Distribution in the USA and Germany: Introducing an Adjusted Wage Share Indicator.” In T. Niechoj, Ö. Onaran, E. Stockhammer, A. Truger and T. van Treeck (Eds.), Stabilising an Unequal Economy? Public Debt, Financial Regulation, and Income Distribution. Marburg, Germany: Metropolis.

- 2012. "Financialization and the Rentier Income Share - Evidence from the USA and Germany." International Review of Applied Economics 26(4): 465-87.

Dutt, A. K. 1984. "Stagnation, Income Distribution and Monopoly Power." Cambridge Journal of Economics 8(1): 25-40.

Eichner, A. 1976. The Megacorp and Oligopoly. Cambridge, UK: Cambridge University Press.

Epstein, G. A. (Ed.) 2005. Financialization and the World Economy. Cheltenham, UK: Edward Elgar.

Epstein, G. A. and A. Jayadev. 2005. "The Rise of Rentier Incomes in OECD Countries: Financialization, Central Bank Policy and Labor Solidarity.” In G. A. Epstein (Ed.), Financialization and the World Economy. Cheltenham, UK: Edward Elgar.

Epstein, G. A. and D. Power. 2003. "Rentier Incomes and Financial Crises: An Empirical Examination of Trends and Cycles in Some OECD Countries." Working Paper Series No. 57. Amherst, MA: Political Economy Research Institute, University of Massachusetts-Amherst.

European Commission. 2007. Employment in Europe. Brussels, Belgium: European Commission.

—_. 2012. AMECO Database, Spring 2012. Brussels, Belgium: European Commission. http://ec.europa.eu/economy_finance/db_indicators/ameco/index_en.htm

Fitoussi, J.-P. and J. Stiglitz. 2009. "The Ways out of the Crisis and the Building of a More Cohesive World.” OFCE Document de Travail No. 2009-17. Paris, France:

L'Observatoire français des conjonctures économiques.

Glyn, A. 2009. "Functional Distribution and Inequality." In W. Salverda, B. Nolan, and T. M. Smeeding (Eds.), The Oxford Handbook of Economy Inequality. Oxford, UK: Oxford University Press.

Gordon, R. and I. Dew-Becker. 2007. "Selected Issues in the Rise of Income Inequality." Brooking Papers on Economic Activity 2: 169-90. 
Gu, G. C. and F. S. Lee. 2012. "Prices and Pricing." On J. King (Ed.), The Elgar Companion to Post Keynesian Economics, $2^{\text {nd }}$ edition. Cheltenham, UK: Edward Elgar.

Guttmann, R. 2009. Asset Bubbles, Debt Deflation, and Global Imbalances.” International Journal of Political Economy 38: 46-69.

Harcourt, G. and P. Kenyon. 1976. "Prices and Investment Decision.” Kyklos 29: 449-77.

Hein, E. 2006. "Interest, Debt and Capital Accumulation - A Kaleckian Approach."

International Review of Applied Economics 20(3): 337-52.

- 2007. "Interest Rate, Debt, Distribution and Capital Accumulation in a Post-Kaleckian Model." Metroeconomica 57(2): 310-39.

- 2008. Money, Distribution Conflict and Capital Accumulation: Contributions to “Monetary Analysis.” Basingstoke, UK: Palgrave Macmillan.

—. 2010a. "A Keynesian Perspective on 'Financialisation." In P. Arestis and M. Sawyer (Eds.), $21^{\text {st }}$ Century Keynesian Economics, International Papers in Political Economy. Basingstoke, UK: Palgrave Macmillan.

- 2010b. "Shareholder Value Orientation, Distribution and Growth - Short- and Medium-Run Effects in a Kaleckian Model.” Metroeconomica 61(2) 302-32.

- 2012. The Macroeconomics of Finance-dominated Capitalism - and its Crisis. Cheltenham, UK: Edward Elgar.

Hein, E., M. Lavoie, and T. van Treeck. 2011. "Some Instability Puzzles in Kaleckian Models of Growth and Distribution: A Critical Survey" Cambridge Journal of Economics 35(3): 587-612.

- 2012. "Harrodian Instability and the 'Normal Rate' of Capacity Utilisation in Kaleckian Models of Distribution and Growth - A Survey." Metroeconomica 63(1): 139-69.

Hein, E. and M. Mundt. 2012. "Financialisation and the Requirements and Potentials for WageLed Recovery - A Review Focusing on the G20." Conditions of Work and Employment Series No. 37. Geneva, Switzerland: International Labour Organization.

Hein, E. and C. Ochsen. 2003. "Regimes of Interest Rates, Income Shares, Savings, and Investment, a Kaleckian model and Empirical Estimations for Some Advanced OECDEconomies." Metroeconomica 54(4): 404-33.

Hein, E. and C. Schoder. 2011. "Interest Rates, Distribution and Capital Accumulation - A Post-Kaleckian Perspective on the U.S. and Germany." International Review of Applied Economics 25(6): 693-723. 
Hein, E. and E. Stockhammer. 2010. "Macroeconomic Policy Mix, Employment and Inflation in a Post-Keynesian Alternative to the New Consensus Model." Review of Political Economy 22(3): 317-54.

Hein, E. and T. van Treeck. 2010a. "'Financialisation' and Rising Shareholder Power in Kaleckian/Post-Kaleckian Models of Distribution and Growth." Review of Political Economy 22(2): 205-33.

- 2010b. "“Financialisation' in Post-Keynesian Models of Distribution and Growth - A Systematic Review." In M. Setterfield (Ed.), Handbook of Alternative Theories of Economic Growth. Cheltenham, UK: Edward Elgar.

Horn, G., K. Dröge, S. Sturn, T. van Treeck, and R. Zwiener. 2009. "From the Financial Crisis to the World Economic Crisis. The Role of Inequality." IMK Policy Brief, October 2009. Duesseldorf, Germany: Macroeconomic Policy Institute IMK at Hans-Boeckler Foundation.

IMF. 2007a. World Economics Outlook, April. Washington, DC: International Monetary Fund.

- 2007b. World Economic Outlook, October. Washington, DC: International Monetary Fund.

Kalecki, M. 1937. “The Principle of Increasing Risk.” Economica 4(16): 440-47.

- 1954. Theory of Economic Dynamics. London, UK: George Allen and Unwin.

-1971. Selected Essays on the Dynamics of Capitalist Economy, 1933-1970. Cambridge, UK: Cambridge University Press.

Krippner, G. R. 2005. "The Financialization of the American Economy." Socio-Economic Review 3(2): 173-208.

Kristal, T. 2010. “Good Times, Bad Times. Postwar Labor's Share of National Income in Capitalist Democracies.” American Sociological Review 75(5): 729-63.

Lavoie, M. 1992. Foundations of Post Keynesian Economic Analysis. Aldershot, UK: Edward Elgar. 1993. "A Post-Classical View of Money, Interest, Growth and Distribution.” In G. Mongiovi and C. Rühl (Eds.), Macroeconomic Theory, Diversity and Convergence. Cambridge, UK: Cambridge University Press.

— . 2002. "The Kaleckian Growth Model with Target Return Pricing and Conflict Inflation." In M. Setterfield (Ed.), The Economics of Demand-led Growth. Cheltenham, UK: Edward Elgar.

Lazonick, W. and M. O’Sullivan. 2000. "Maximizing Shareholder Value: A New Ideology for Corporate Governance.” Economy and Society 29(1): 13-35. 
Lee, F. S. 1998. Post Keynesian Price Theory. Cambridge, UK: Cambridge University Press.

Marterbauer, M. and E. Walterskirchen. 2002. "Bestimmungsgründe der Lohnquote und der realen Lohnstückkosten.” WIFO-Studie. Vienna, Austria: Austrian Institute of Economic Research (WIFO).

Mohun, S. 2006. "Distributive Shares in the US Economy, 1964-2000." Cambridge Journal of Economics 30(3): 347-70.

OECD. 2008. Growing Unequal? Income Distribution and Poverty in OECD Countries. Paris, France: Organisation for Economic Co-operation and Development.

- 2011. Divided We Stand, Why Inequality Keeps Rising. Paris, France: Organisation for Economic Co-operation and Development.

- 2012. OECD, StatExtracts. Paris, France: Organisation for Economic Co-operation and Development. http,//stats.oecd.org/Index.aspx

Palley, T. 2008. "Financialisation, What It Is and Why It Matters." In E. Hein, T. Niechoj, P. Spahn, and A. Truger (Eds.), Finance-led Capitalism? Macroeconomic Effects of Changes in the Financial Sector. Marburg, Germany: Metropolis.

Palma, J. C. 2009. "The Revenge of the Market on the Rentiers. Why Neo-Liberal Reports of the End of History Turned Out to Be Premature." Cambridge Journal of Economics 33(4): 829-69.

Panico, C. 1985. "Market Forces and the Relation between the Rates of Interest and Profit." Contributions to Political Economy 4(1): 37-60.

Piketty, T. and E. Saez. 2003. "Income Inequality in the United States, 1913-1998." The Quarterly Journal of Economics 143: 1-39.

—. 2006. "The Evolution of Top Incomes: A Historical and International Perspective." AEA Papers and Proceedings 96(2): 200-05.

Pivetti, M. 1985. "On the Monetary Explanation of Distribution.” Political Economy 1(2): 73 103. 1991. An Essay on Money and Distribution. Basingstoke, UK: Macmillan.

Rowthorn, R. E. 1977. "Conflict, Inflation and Money." Cambridge Journal of Economics 1(3): 215-39.

_. 1981. "Demand, Real Wages and Economic Growth." Thames Papers in Political Economy (Autumn): 1-39

Sapir, J. 2009. "From Financial Crisis to Turning Point. How the US Subprime Crisis Turned into a World-Wide One and Will Change the Global Economy." Internationale Politik und Gesellschaft 1: 27-44. 
Sraffa, P. 1960. Production of Commodities by Means of Commodities. Cambridge, UK: Cambridge University Press.

Steindl J. 1976. Maturity and Stagnation in American Capitalism, 2nd edition. New York, London: Monthly Review Press.

Stockhammer, E. 2004. The Rise of Unemployment in Europe: A Keynesian Approach. Cheltenham, UK: Edward Elgar.

- 2008. "Some Stylized Facts on the Finance-Dominated Accumulation Regime." Competition and Change 12(2): 189-207.

—. 2009. "Determinants of Functional Income Distribution in OECD Countries." IMK Studies 5/2009. Duesseldorf, Germany: Macroeconomic Policy Institute IMK at HansBoeckler Foundation.

- 2010a. "Income Distribution, the Finance-dominated Accumulation Regime, and the Present Crisis." In S. Dullien, E. Hein, A. Truger, and T. van Treeck (Eds.), The World Economy in Crisis - the Return of Keynesianism? Marburg, Germany: Metropolis.

- 2010b. "Neoliberalism, Income Distribution and the Causes of the Crisis." Research on Money and Finance. Discussion Paper No. 19. London, UK: Department of Economics, SOAS.

Sylos-Labini, P. 1969. Oligopoly and Technical Progress, 2nd Edition. Cambridge, UK: Cambridge University Press.

— 1979. "Prices and Income Distribution in Manufacturing Industry." Journal of Post Keynesian Economics 2(1): 3-25.

Tomaskovic-Devey, D. and K. H. Lin. 2011. Financialization and US Income Inequality, 19702008. http,//ssrn.com/abstract=1954129

UNCTAD. 2009. The Global Economic Crisis: Systemic Failures and Multilateral Remedies. New York, NY and Geneva, Switzerland: United Nations Conference on Trade and Development.

Van Treeck, T. 2009. "The Political Economy Debate on 'Financialisation' - A Macroeconomic Perspective." Review of International Political Economy 16(5): 907-44.

Van Treeck, T., E. Hein, and P. Dünhaupt. 2007. "Finanzsystem und wirtschaftliche Entwicklung, neuere Tendenzen in den USA und in Deutschland." IMK Studies 5/2007. Duesseldorf, Germany: Macroeconomic Policy Institute IMK at Hans-Boeckler Foundation.

Van Treeck, T. and S. Sturn. 2012. "Income Inequality as a Cause of the Great Recession? A Survey of Current Debates." ILO Conditions of Work and Employment Series No. 39. Geneva, Switzerland: International Labour Office. 
Wade, R. 2009. "From Global Imbalances to Global Reorganisations." Cambridge Journal of Economics 33(4): 539-62.

Wood, A. 1975. A Theory of Profits. Cambridge, UK: Cambridge University Press.

Zalewski, D. A. and C. H. Whalen. 2010. "Financialization and Income Inequality, a Post Keynesian Institutionalist Analysis." Journal of Economic Issues 44(3): 757-77. 